\title{
Financial Integration and Foreign Banks in Latin America: Do They Amplify External Financial Shocks?
}

\section{Arturo J. Galindo, Alejandro Izquierdo, and Liliana Rojas-Suarez}

\section{Abstract}

This paper explores the impact of international financial integration on credit markets in Latin America. Using a cross-country dataset covering 17 Latin American countries between 1996 and 2008, the authors find that financial integration amplifies the impact of international financial shocks on aggregate credit and interestrate fluctuations. Despite this pernicious effect, the net impact of integration on deepening credit markets is positive and dominates for the large majority of states of nature. The paper also uses a detailed bank-level dataset covering more than 500 banks in Latin America for a similar time period to explore the role of financial integration - captured through the participation of foreign banks - in propagating external shocks. The authors find that interest rates charged and loans supplied by foreign-owned banks respond more to external financial shocks than those supplied by domestically owned banks. However, this result does not hold for all foreign banks: Spanish banks in the sample behave more like domestic banks and do not amplify the impact of foreign shocks on credit and interest rates. Important policy recommendations to avoid foreign banks' amplification of external financial shocks include the establishment of ring-fencing mechanisms, the development of early-warning systems, and the incorporation for agreements between domestic and foreign supervisors.

JEL Codes: F36, G0, G21

Keywords: foreign banks, credit, interest rates, financial shocks

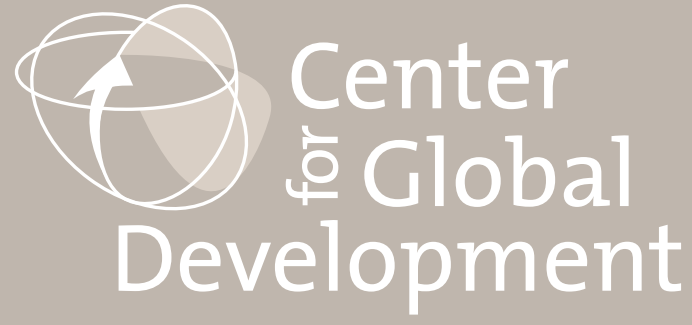

\section{Working Paper 203 January 2010}




\title{
Financial Integration and Foreign Banks in Latin America: Do They Amplify External Financial Shocks?
}

\author{
Arturo J. Galindo \\ Inter-American Development Bank \\ Alejandro Izquierdo \\ Inter-American Development Bank \\ Liliana Rojas-Suarez \\ Center for Global Development
}

The authors would like to thank Gian Maria Milesi-Ferretti, Enrique Alberola and seminar participants at the Center for Global Development for their valuable comments, as well as Verónica Gonzales and Cesar Tamayo for superb research assistance. We also thank Gian Maria Milesi-Ferretti for providing us with an update of the financial integration data.

Arturo J. Galindo, Alejandro Izquierdo, and Liliana Rojas-Suarez. 2010. "Financial Integration and Foreign Banks in Latin America: How Do They Impact the Transmission of External Financial Shocks?" CGD Working Paper 203. Washington, D.C.: Center for Global Development. http:/www.cgdev.org/content/publications/detail/1423751

Center for Global Development 1800 Massachusetts Ave., NW Washington, DC 20036

202.416.4000

(f) 202.416 .4050

www.cgdev.org
The Center for Global Development is an independent, nonprofit policy research organization dedicated to reducing global poverty and inequality and to making globalization work for the poor. Use and dissemination of this Working Paper is encouraged; however, reproduced copies may not be used for commercial purposes. Further usage is permitted under the terms of the Creative Commons License.

The views expressed in this paper are those of the author and should not be attributed to the board of directors or funders of the Center for Global Development. 


\section{Introduction}

Since the 1990s, most countries in Latin America have embarked in a process of financial integration characterized by a reduction of impediments to cross-border financial transactions and an increased participation of foreign banks in the local banking systems. ${ }^{1}$ By 2007 , Latin America as a whole was the most financially open region in the developing world. ${ }^{2}$ Accompanying these developments, a large and increasing literature on this topic has emerged. However, no consensus has been reached regarding the relative benefits and perils of both increased financial integration and greater participation of foreign banks.

The global financial crisis that started in 2007 in major industrialized countries heated this debate further. In the view of some analysts, the propagation of the crisis from developed countries to emerging market economies in general- and Latin America in particular- through financial channels is proof of the need to impose limits to financial integration. The sharp reduction in access to international capital markets experienced by Latin American countries in the last part of 2008 and the beginning of 2009 and the resulting adverse effects on growth and economic stability is cited as evidence of the dangers of liberalized capital accounts. ${ }^{3}$

Others, however, focus on the rapid growth experienced by the region in the five years that preceded the crisis and argue that greater financial integration and active participation of foreign banks played an important role in that outcome. While acknowledging the adverse effects of contagion during the crisis, this group of experts argues that the low savings rates prevalent in most countries in the region impose a greater constraint on long-term growth than the short-term negative impact of the international crisis.

The importance of financial integration and foreign banks in Latin America, however, goes beyond its effect on economic growth. These two factors also play a crucial role in the behavior of real credit growth and real interest rates. Interestingly enough, when analyzing these issues, most of the analytical literature deals with the response of local financial variables to real shocks, such as a reduction in economic activity either in the local economy or in the home country of foreign banks (see the literature discussion in section II). In contrast, analyses on the role of financial integration and foreign banks in the transmission of external financial shocks (such as a sharp increase in the US high yield spread), to domestic credit and interest rates in Latin America are extremely limited.

This paper aims to help fill that vacuum and complement existing literature by conducting an empirical investigation on the relationship between domestic financial variables (real credit growth and real interest rates) and external financial shocks reflecting a change in investors' perception of risk (such as a drastic increase in the VIX index, the EMBI spread or the spread on

\footnotetext{
${ }^{1}$ Exceptions to this trend include Venezuela and, more recently, Argentina and Ecuador.

${ }^{2}$ See section III and Rojas-Suarez (2009).

${ }^{3}$ See, for example, Stiglitz (2009)
} 
US high yield bonds). The novelty of the analysis lies in determining the role of both financial integration and foreign banks in this interrelationship. Thus, the key questions answered in this paper for Latin America are: (a) Does financial integration amplify the adverse effect of an increase in investors' perceptions of risk on domestic credit? (b) Does the behavior of foreign banks differ from that of domestic banks in terms of the response of credit to an adverse external financial shock? And (c) Do foreign banks increase interest rates more than domestic banks when a negative external financial shock hits the local financial system?

The empirical investigation provides a positive answer to these questions. However, despite this pernicious effect, the research also concludes that the net impact of financial integration supports real credit growth and lower real interest rates. Thus, while financial integration is a channel through which adverse financial shocks lead to credit contractions and increases in interest rates, it also helps credit markets to deepen and the cost of finance to decline in the absence of adverse external financial shocks. Moreover, this latter effect dominates the former.

The rest of this paper is organized as follows. Section II presents a brief review of the literature on the benefits and risks of financial integration and foreign banks in emerging markets. Section III discusses the extent of financial integration in Latin America using both de jure and de facto measurements. This section also shows some changes in the characteristics of international loans to the region that accompanied the process of financial integration. Section IV conducts an empirical analysis to determine the role of financial integration in the relationship between external financial shocks and domestic real credit growth and real interest rates. The section also explores whether, in the presence of an external financial shock, the behavior of domestic banks differs from that of foreign banks. Section $\mathrm{V}$ advances some policy recommendations and Section VI concludes.

\section{Financial Integration and Foreign Banks in Emerging Markets: a Brief Literature Review}

Financial integration has been the subject of much debate, particularly following the emerging market crises in the late 1990s, with ambiguous weights on the pros and cons of capital account liberalization policies. Despite the large provision of funding that supported growth

processes in emerging markets, stark financial crises that stemmed from supply shocks to the provision of international credit and their associated output meltdowns (as shown, for example by Calvo, Izquierdo and Talvi (2006)) led to a rethinking of financial integration strategies. The current global financial crisis poses once again similar questions about desired integration levels in a context of repeated international financial volatility. Although capital account liberalization seems to have brought several benefits to those who engaged in these policies - as evidenced by large expansionary cycles during the mid-2000s - it has not been without costs. However, recent work by Ranciere, Tornell and Westermann (2008) suggests that the benefits seem to outweigh 
costs in that countries that have experienced occasional financial crises have, on average, grown faster than countries with stable financial conditions, suggesting a positive effect of integration with systemic risk on growth ${ }^{4}$. Thus, situations of greater incidence of crisis are compatible with higher mean growth. As a matter of fact, Ranciere, Tornell and Westermann (2006) provide an empirical decomposition of the effects of financial liberalization on growth and on the incidence of crises, and show that the direct effect of financial liberalization on growth outweighs by far the negative indirect effect of a higher propensity to crisis ${ }^{5}$. Recent work by Calvo and LooKung (2009) also suggests that in terms of consumption welfare, periods of financial liberalization accompanied by high growth do not need to be very long in order to beat the alternative of lower growth, closed capital account processes. ${ }^{6}$

Financial integration has been accompanied in many cases by larger participation of foreign banks. Thus, it is relevant to understand how foreign banks contribute or detract from credit volatility. Foreign banks may play a stabilizing role in that they can better diversify risk, and they can rely on parental liquidity and capital back up under host-country shocks. For example, Goldberg (2002) shows that international activities of foreign banks headquartered in the US are not influenced by host country economic conditions. Moreover, Goldberg (2005) finds that local and cross border claims on Latin American customers of U.S. banks are not robustly related to country-specific business cycle variables. Galindo, Micco and Powell (2003) bring in additional support to these findings by establishing that foreign banks can stabilize credit during domestic deposit crunches.

In a similar vein, Martinez Peria, Powell and Vladkova-Hollar (2005) present evidence that the sensitivity of foreign bank claims to host-country factors diminishes as banks' aggregate exposure rises. They also infer that foreign bank claims react more to positive than to negative host shocks and that they are not significantly curtailed during crises. De Haas and Lelyveld (2006) find additional evidence for Central and Eastern Europe that during crisis periods, domestic banks contract their credit and deposit bases, whereas foreign banks do not. More recently, Cull and Martinez Peria (2007) report that although countries that experienced a banking crisis tended to have higher levels of foreign bank participation than those that did not, foreign participation increased as a result of crises rather than prior to them.

However, research also indicates that foreign banks can amplify credit cycles driven by changes in business opportunities in the domestic economy. For example, although Morgan and Strahan (2003) show that foreign banks may dampen the effect of a general bank capital shock on firm investment in the host country - in line with the literature mentioned above - they also

\footnotetext{
${ }^{4}$ In similar lines, Galindo, Micco and Ordoñez (2002) show that financial liberalization exerts a positive impact in the growth rate of economic sectors that rely more on external finance.

${ }^{5}$ Other work showing positive effects of financial liberalization on growth include Galindo, Schiantarelli and Weiss (2007) who show that the allocation of investment is more efficient where financial liberalization is greater.

${ }^{6}$ This does not mean that processes of high growth accompanied by crises are desirable. Indeed, emerging markets are continuously struggling to integrate financially in ways that do not pose significant danger leading to financial crises.
} 
find that foreign banks can amplify firm collateral shocks in the host country by reallocating their portfolio when changes in expected risk/return take place. This exploits alternative investment opportunities abroad, which is an option that may not be available to domestic banks. Similarly, Galindo, Micco and Powell (2003) determine that when foreign banks suffer a shock to expected returns in the host country, they may cut back on local operations at a faster pace than less diversified domestic banks. These findings point to the fact that under particular conditions there may be a positive association between a host country's business cycle and foreign bank credit supply.

Apart from the above mentioned reaction to host country shocks, also known as pull" factors, several studies have focused on -push" factors linked to the impact of source country shocks on host country lending by foreign banks. Goldberg (2005) finds that U.S. banks' claims on European markets have been generally positively correlated with U.S. GDP growth, implying that net claims abroad increase when the U.S. economy is expanding. Peek and Rosengreen (2000) present similar evidence on pro-cyclical flows when studying US exposure to the Japanese cycle. They find that exposure to the Japanese real estate bubble of the early 1990s led to a contraction of credit from Japanese banks to U.S. customers. Kamil and Rai (2009) show that liquidity constraints in the U.S. money markets reduce cross border lending and foreign bank subsidiary lending to Latin American countries.

However, Goldberg (2005) finds that cross border claims on Latin American markets are not robustly related to the U.S. business cycle and thus, U.S. banks do not appear to be strong conduits for transmitting U.S. cycles to smaller markets. Despite this finding on push" factors indicating that apparently foreign banks do not seem to import source country shocks into Latin America, little has been explored in terms of the relevance of external shocks related to changes in risk aversion - such as sharp changes in US high yield spreads, global EMBI spreads, or the VIX index - on foreign bank lending behavior vis-à-vis that of domestic banks. Similarly, although much has been written about financial integration and banking crises, there is a need to explore whether larger financial integration significantly impacts on domestic credit fluctuations and real interest rates when systemic risk aversion rises. This issue will be tackled empirically in Section IV.

\section{How Integrated is Latin America to International Financial Markets?}

International financial Integration can be measured in two alternative ways: de jure and de facto. The former assesses the regulatory restrictions (or lack of) on cross-border financial transactions of financial institutions. The latter measures the extent to which cross-border holdings of financial assets and liabilities have actually taken place. While in general, one could expect that both measures would be highly correlated in an increasingly globalized world it is also quite possible to envision situations in which such correlation does not materialize. For 
example, a country with a fully-liberalized capital account might encounter very little interest of foreign investors in the country's assets and financial instruments due to its high economic and/or political instability. Likewise, it is also possible that large accumulation of foreign assets and liabilities occurs in spite of existing capital account controls, if those controls prove to be ineffective ${ }^{7}$. A review of the literature shows that examples on both cases abound in the recent history of Latin America ${ }^{8}$.

Regardless of the desirability and effectiveness of capital controls - a topic not addressed in this paper- a relevant issue is to understand the degree and evolution of financial integration in Latin America, both de jure and de facto. This section explores those matters. At the outset however, it is important to clarify that the measures discussed here are approximations; it is extremely difficult to fully distinguish between these two kinds of measurements. As explained above, unstable macro policies can de facto be an impediment to financial integration, even in the absence of de jure capital controls.

\section{De Jure Financial Integration}

There are a number of alternative measures of capital account liberalization (or, conversely, capital controls). For the purpose of allowing country comparisons, all these measures are based on information provided by the IMF's Annual Report on Exchange Arrangements and Exchange Restrictions (AREAER), which reports the extent of rules and regulations affecting cross-border financial transactions. ${ }^{9}$ In this paper we use the index of financial openness developed by Chinn and Ito (2007), which attempts to capture the extent and intensity of restrictions to capital mobility. The Chinn and Ito index is based on information from AREAER, and the index uses a principle components methodology to achieve its purpose. The higher the value of the index, the more open the capital account. ${ }^{10}$

Figure 1 presents the evolution of the financial openness index by regions. ${ }^{11}$ As the chart clearly shows, the Latin American index of capital account liberalization has been increasing since the 1990s, and by 2006 this region was the most financially open region in the world, second only to developed countries. Indeed, by 2006, Latin America's index of financial openness was triple that of Eastern Europe and Central Asia.

Moreover, as Table 1 shows, the majority of Latin American countries display a very high degree of financial openness and an increasing trend. By 2006, only four countries presented limited openness: Argentina, Colombia, Honduras and Venezuela, with the indicator

\footnotetext{
${ }^{7}$ See for example Edwards (1999)

${ }^{8}$ The literature on the desirability and effectiveness of capital controls is quite large, especially for Latin America. For a review, see Magud and Reinhart (2007). This paper does not deal with this issue.

${ }^{9}$ See, for example Glick and Hutchison (2001) and Quinn (2003)

${ }^{10}$ In this index, by construction, the value of the series has a mean of zero.

${ }^{11}$ Each regional value for every year is simply the average of the value of the index for all countries within the region.
} 
significantly deteriorating in the cases of Argentina and Venezuela. Although the index is not estimated after 2006, recent policy decisions in Ecuador imply that this country has joined Argentina and Venezuela in the imposition of restrictions to the capital account. By contrast, Colombia has recently lifted a number of capital controls. ${ }^{12}$

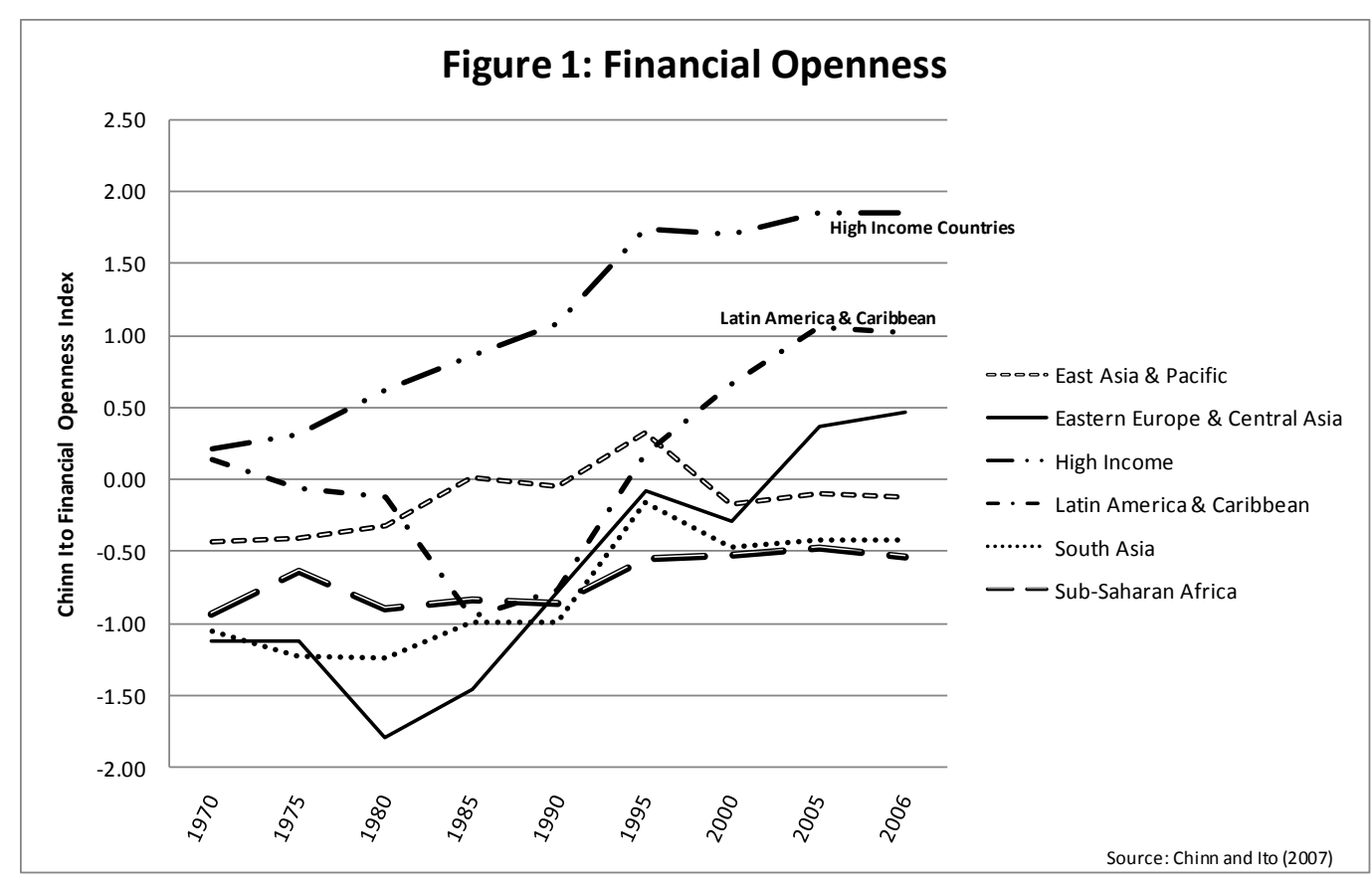

\footnotetext{
${ }^{12}$ In late 2009, Brazil introduced mild capital controls. Foreign direct investment, which constitutes the lion's share of inflows to Brazil were exempted. The controls consist on requiring foreign investors to pay a $2 \%$ tax when they buy reales--the Brazilian currency-- for the purpose of acquiring fixed-income instruments or equities in the local markets. Although the intention was to contain the appreciation of the local currency, at the time of this writing the controls were ineffective as the Real continued its appreciation path, and it was no clear whether the controls would remain in place for a long period of time.
} 
Table 1

Financial Openness Index in Latin America, 1970-2006

\begin{tabular}{|c|c|c|c|c|c|}
\hline Country & 1970 & 1980 & 1990 & 2000 & 2006 \\
\hline Argentina & 0.72 & -0.09 & -1.13 & 1.73 & -0.76 \\
\hline Bolivia & 1.27 & 1.27 & 0.60 & 1.50 & 1.50 \\
\hline Brazil & -1.80 & -1.80 & -1.80 & -1.13 & 1.27 \\
\hline Chile & -1.80 & -0.09 & -1.80 & -1.13 & 2.54 \\
\hline Colombia & -1.80 & -1.80 & -1.13 & -1.13 & -0.09 \\
\hline Costa Rica & 1.27 & -0.49 & -1.80 & 1.27 & 1.27 \\
\hline Dominican Republic & -1.13 & -1.80 & -1.80 & -0.44 & 2.54 \\
\hline Ecuador & 0.99 & 0.60 & -0.98 & -0.09 & 2.27 \\
\hline El Salvador & -1.13 & -1.13 & -1.80 & 2.54 & 2.54 \\
\hline Guatemala & -1.13 & -0.05 & -0.22 & 1.27 & 2.54 \\
\hline Honduras & 2.54 & 0.99 & -1.80 & -0.09 & -0.09 \\
\hline Mexico & 2.54 & 2.54 & -0.76 & 1.19 & 1.19 \\
\hline Nicaragua & 2.54 & -1.26 & -1.13 & 2.54 & 2.54 \\
\hline Panama & 2.54 & 2.54 & 2.54 & 2.54 & 2.54 \\
\hline Paraquav & -1.13 & -0.76 & -1.13 & 1.50 & 1.50 \\
\hline Peru & -0.71 & 0.06 & -1.80 & 2.54 & 2.54 \\
\hline Uruguay & -0.59 & 0.72 & 1.27 & 2.54 & 2.54 \\
\hline Venezuela & 0.60 & 1.87 & -0.09 & 2.54 & -0.71 \\
\hline
\end{tabular}

Source: Chinn and Ito (2007).

A discussion of the factors behind the high level of financial openness in Latin America can be found in Rojas-Suarez (2009). For the purpose of this paper, it is sufficient to recall that the impetus toward capital account liberalization started in the 1990s with the implementation of the Brady Plan that allowed for the securitization of governments' external liabilities as a way to resolve the debt crisis of the 1980s that had paralyzed the region for a decade. Since then, a highly liquid market for international bonds and other securities issued by Latin American countries has developed. This, together with extremely low national savings rates, implies that most countries in the region highly depend on foreign capital to meet their financing needs and are subject to the volatility of capital flows.

While increased access to international capital markets has certainly supported growth prospects in the region, it has also brought about important risks, especially as demonstrated by the current international financial crisis. However, in spite of the current deep uncertainties in international capital markets, there are no indications that Latin America as a whole will cease to be the most financially open developing region in the foreseeable future. Instead, most countries have placed the achievement (or maintenance) of investment grade among their top priorities and, to this end, countries have made significant progress in avoiding deviations from macroeconomic stability. ${ }^{13}$

\footnotetext{
${ }^{13}$ Not surprisingly, the countries with weaker macroeconomic indicators: Argentina, Ecuador and Venezuela are also the countries with more controls on cross-border transactions. Also, Argentina and Ecuador defaulted on their external debt obligations in the early 2000 s.
} 


\section{De Facto Financial Integration}

A well-known measure of actual financial integration is that developed by Lane and MilesiFerretti (LM-F) (2007), who assembled a data set on foreign assets and liabilities of 145 countries over the period 1970-2004. Lane and Milesi-Ferretti also produced an updated and extended version using the same methodology of LM-F (2007) while covering the period 1970$2004 .{ }^{14}$ Since this measure of financial integration cannot fully capture the participation of foreign financial institutions (beyond foreign direct investment and other forms of external financing), a separate sub-section presents data on the participation of foreign banks in the region.

\section{a. The Value of Cross-Border Holdings in Latin America}

Following LM-F, a measurement of de facto financial integration is defined as the sum of the stocks of (the absolute value of) external assets plus external liabilities as a percentage of GDP. ${ }^{15}$ Data for the period 1970-2007 are directly taken from LM-F (2007 and updates). Figure 2 shows the evolution of this indicator for Latin America. The data in Figure 2 consist of simple regional averages of the information gathered for individual countries.

\footnotetext{
${ }^{14}$ The authors are very grateful to Milesi-Ferretti for sending the updated data set.

${ }^{15}$ Measures of financial integration were scaled by a county's GDP in US dollars. In order to avoid the effect of large real exchange rate (RER) swings on dollar GDP valuation, so common in the region, we constructed adjusted GDP series in US dollars under a constant RER assumption, using 2003 as the base year. Consider current GDP in US dollars for any given year:

$$
G D P_{t}^{U S}=G D P_{t-1}^{U S} \times\left[\frac{\left(+g_{t} \times\left(1+p_{t}\right)\right.}{1+e_{t}}\right]_{(\text {a) }}
$$

where $\mathrm{g}, \mathrm{p}$ and $\mathrm{e}$ stand for real GDP growth, domestic inflation and nominal exchange rate depreciation, respectively. In order to hold the RER constant, then the following must hold:

$$
\left(1+p_{t}\right)=\left(1+e_{t}\right) \times\left(1+p_{t}^{*}\right)(\mathrm{b})
$$

where $p_{t}^{*}$ stands for foreign inflation. Substituting (b) into (a) yields:$$
G D P_{t}^{U S}=G D P_{t-1}^{U S} \times\left(1+g_{t}\right) \times\left(1+p_{t}^{*}\right) \text { (c) }
$$

Taking 2003 GDP in current US dollars as the base year, series for adjusted GDP in US dollars were constructed making use of (c).
} 


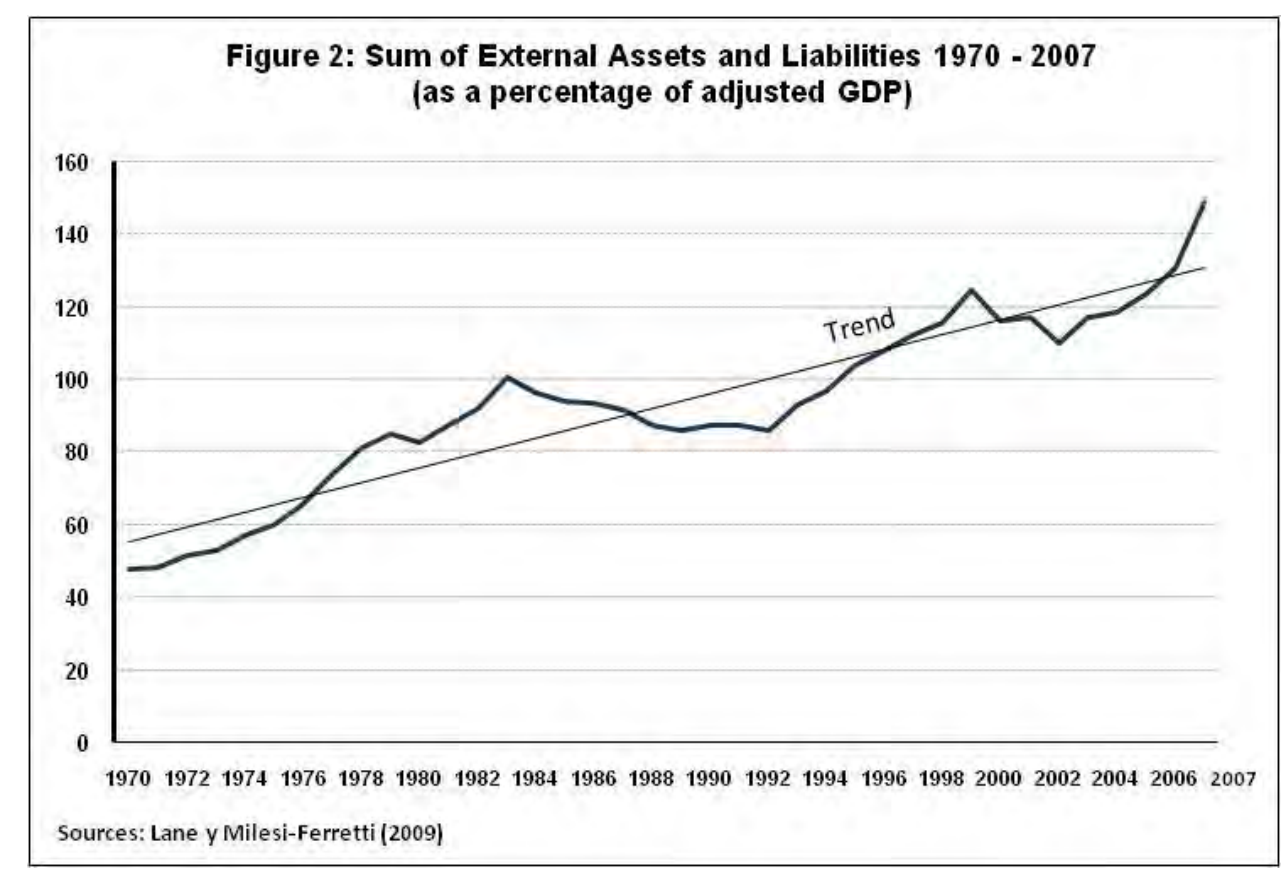

Consistent with global developments, the trend of accumulation of international assets and liabilities has been significantly positive in Latin America. The two periods when the indicator of financial integration declined, the 1980s and the period from late 1990s to the early 2000s, were periods when sharp economic and financial crises plagued the region and led to a reversal of net capital inflows to Latin America (therefore, reducing the accumulated international stock of assets and liabilities). Not surprisingly, data for the period 2004-2007 show a rapid increase in the indicator. In the context of the current international financial crisis, and as additional data become available, it is expected to observe a decline in the indicator in 2008.

The data also shows that, although lagging significantly behind industrial countries in terms of financial integration, Latin America is de facto one of the most financially integrated regions in the developing world.

But increased financial integration has not only meant increased values of cross-border financial assets and liabilities; it has also implied important changes in some of the characteristics of these stocks. For example, information from the BIS (Bank for International Settlements) allows us to illustrate two features of international bank lending to Latin America that have been changing dramatically since the 1990s. The first one deals with the composition of international bank claims between the public and private sectors. As shown in Figure 3, in the early 1990s, when the process of financial integration was at its early stage, a large proportion (about 50 percent) of lending from BIS reporting banks towards the region was directed to the public sector. In sharp contrast, by 2007 more than 90 percent of international bank lending was directed to the private sector. This development is consistent with the market-led growth model adopted by most countries in the region in the last decade. 


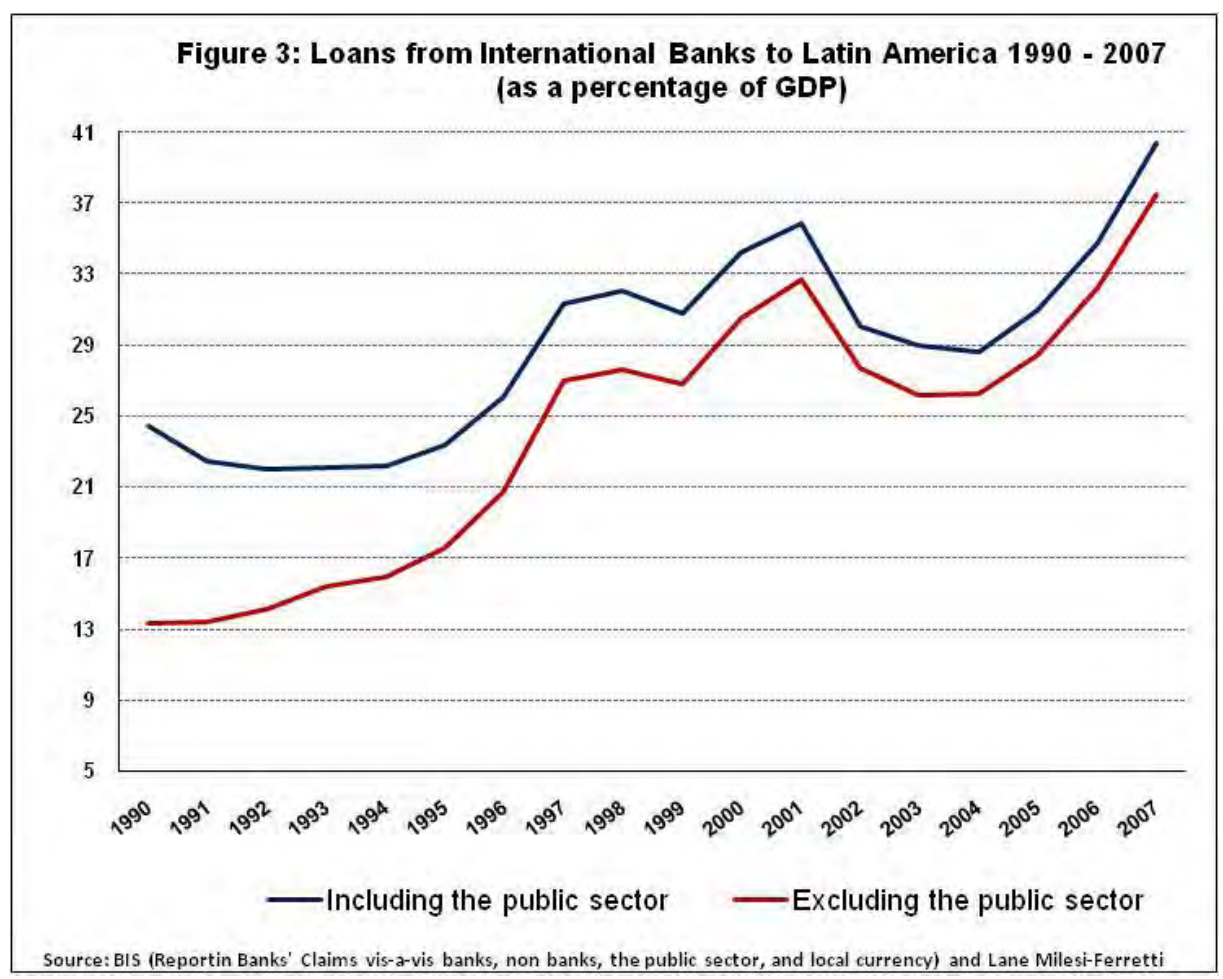

The second feature is the maturity of international loans to the region. In the mid 1990s more than 50 percent of international claims to Latin America had a maturity of one year or less. In some countries, such as El Salvador and Guatemala this value reached over 80 percent. Since then, the average maturity of these loans has increased consistently and, by 2008, the percentage of short-term international bank claims in total international bank claims to the region declined to 40 percent (see Figure 4)

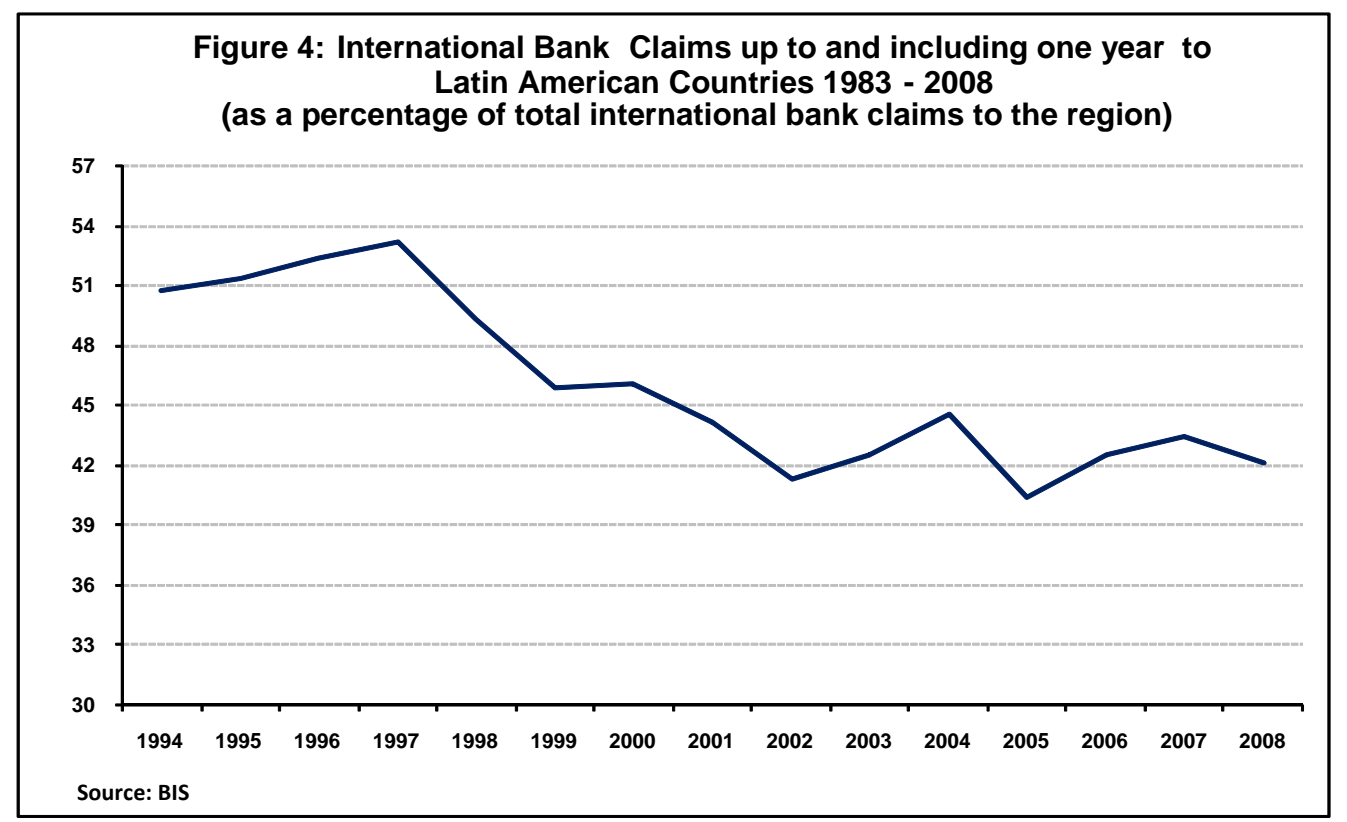


In the context of a favorable external environment in the period 2003-2007, increased financial integration of Latin America, combined with improved regulatory and supervisory domestic frameworks, gave the region a greater availability of sources of finance on better terms and conditions than in the previous two decades.

\section{b. The Participation of Foreign Banks in Local Financial Systems}

An important component of the process of financial integration in Latin America, not captured by data on cross-border transactions is the participation of foreign banks in local financial systems. Increased participation of foreign banks started in the mid-1990s due to two major factors, depending on the country. Firstly, consistent with capital account liberalizations, many countries in the region began to liberalize their domestic financial systems which significantly reduced government interference in the activities of commercial banks. This, together with privatization of public banks, created incentives for foreign investment in local banking systems. Secondly, in the context of the severe banking crises experienced during the 1990s, the need to recapitalize banks in required efforts to attract foreign capital into local banking systems. Mexico was an example of this development.

Measured by the percentage of total assets in the local banking system, the participation of foreign banks varied widely across Latin American countries by 2007. As shown in Table 2, El Salvador and Mexico stand out (by a large margin) as the countries with the highest participation of foreign banks in the region (with over 85 percent of total assets of the banking system). In contrast, foreign bank participation is very low in Ecuador and Venezuela. Moreover, while in some countries foreign bank participation has increased, in others it has remained stable, and yet in others, the participation of foreign banks has significantly declined. Argentina is a clear example of the latter. As a result of the inadequacies in the resolution of the Argentinean banking crisis in 2001, parent companies of several international banks reduced their presence in that country. 


\begin{tabular}{lc}
\multicolumn{2}{c}{$\begin{array}{c}\text { Table 2 } \\
\text { Participation of Foreign Banking }\end{array}$} \\
\multicolumn{2}{c}{ COUNTRY } \\
\hline \multicolumn{1}{c}{ (as a percentage of the total of assets in the system) } \\
\hline ARGENTINA & $\mathbf{2 0 0 7}$ \\
BOLIVIA & $19.2 \%$ \\
BRAZIL & $37.7 \%$ \\
CHILE & $16.8 \%$ \\
COLOMBIA & $40.3 \%$ \\
COSTA RICA & $21.8 \%$ \\
DOMINICAN REPUBLIC & $20.5 \%$ \\
ECUADOR & $9.9 \%$ \\
EL SALVADOR & $4.5 \%$ \\
GUATEMALA & $93.1 \%$ \\
HONDURAS & $9.9 \%$ \\
MEXICO & $36.1 \%$ \\
NICARAGUA & $85.4 \%$ \\
PARAGUAY & $20.5 \%$ \\
PERU & $58.9 \%$ \\
URUGUAY & $50.6 \%$ \\
VENEZUELA & $43.7 \%$ \\
\hline Source: Bankscope & $1.8 \%$ \\
\hline
\end{tabular}

\section{How do Financial Integration and Foreign Banks Transmit International Financial Shocks?: An Empirical Investigation}

The literature review presented in section II discussed the response of foreign banks operations in Latin America to shocks generated in local economies and to changes in economic activity in the home country of foreign banks. Here, we empirically assess the response of foreign banks to external financial shocks, reflecting a change in risk aversion -a key issue in the context of the current international financial crisis.

We explore the effect of external financial shocks on domestic financial variables from two complementary angles. Firstly, we use cross-country data for a set of Latin American countries to assess the impact of changes in external financial conditions reflecting investors' perceptions of risk on the real growth rate of credit and on real interest rates. As part of this investigation, we explore the role played by financial integration in propagating external financial fluctuations to domestic variables. Secondly, we use a detailed database of bank-level balance sheets to analyze the response of real credit growth and real interest rates of specific banks to external financial fluctuations and explore whether the response varies according to the ownership structure of the bank (namely whether the bank is domestic or foreign owned). 


\section{Cross-Country Methodology and Results}

We use a quarterly dataset for 18 Latin American and Caribbean ${ }^{16}$ countries spanning the period of 1996-2008, including data from the IMF's International Financial Statistics, Bloomberg and country-specific statistical agencies to estimate the impact of changes in international financial conditions on the real growth rate of credit and real interest rates in Latin American countries.

We measure international financial conditions using two indicators of investors' perceptions of risk: the spread of high-yield bonds and the VIX index (both in $\operatorname{logs})^{17}$. Our main objective is to assess the correlation between the riskiness of international financial conditions and domestic financial variables, and analyze whether this relationship depends on the degree of integration with international financial markets.

We estimate the following regression:

$$
\begin{aligned}
& X_{i t}=\alpha_{1} \Delta \log \left(I P_{i t-1}\right)+\alpha_{2} \Delta \log \left(I P_{i t-1}\right) * I n t_{i t-1}+ \\
& \beta_{1} Y_{t}+\beta_{2} Y_{t} * I n t_{i t-1}+\gamma I n t_{i t-1}+\mu_{i}+d+\varepsilon_{i t}
\end{aligned}
$$

where $i$ denotes a country and $t$ a time period, $X$ is either the real growth rate of credit or the real interest rate. Real credit growth is calculated as the difference in the logarithm of real credit which is nominal credit supplied by the domestic banking system to the private sector deflated by the CPI (Consumer Price Index). The real interest rate is calculated using the one-period ahead observed inflation rate as a measure of inflation expectations ${ }^{18}$. IP is the country's industrial production. Int is a measure of financial integration, which corresponds to the de facto measure of financial integration discussed in section III, namely the measure developed by LM-F (2006). $Y$ is a variable measuring international financial conditions (in some specifications we use the log of the high-yield spread, in others the log of the VIX index), $\mu_{i}$ are country fixed effects, $d$ are seasonal dummies, and $\varepsilon$ is a residual ${ }^{19}$.

In equation (1) we allow the dependent variable of interest to relate to changes in the lagged level of economic activity measured by the industrial production index, to international

\footnotetext{
16 The countries included in the dataset are determined by data availability. The countries in the sample are: Argentina, Bolivia, Brazil, Chile, Colombia, Costa Rica, Ecuador, Guatemala, Honduras, Haiti, Mexico, Nicaragua, Peru, Paraguay, El Salvador, Trinidad and Tobago, Uruguay and Venezuela. Data was also available for Panama, but this country was not included in the analysis because it is a financial center and our data sources do not allow for a distinction between domestic and international banking activities.

17 The high-yield spread is the difference between the return of US high-yield bonds (non investment-grade bond, speculative-grade bond or junk bond) and the return of US Treasuries. A higher spread indicates higher risk. The VIX is the ticker symbol for the Chicago Board Options Exchange Volatility Index. This is a commonly used measure of the implied volatility of S\&P 500 index options. A high value corresponds to a more volatile market.

${ }^{18}$ For simplicity, the real interest rate $(r)$ is computed as $(1+i) /\left(1+\pi^{\mathrm{e}}\right)-1$ where $\mathrm{i}$ is the nominal interest rate and $\pi^{\mathrm{e}}$ is the one-period-ahead observed CPI inflation rate (i.e., assuming perfect foresight).

${ }^{19}$ Data on credit to the private sector, interest rates and consumer price index was taken from IFS, high-yield spreads and the VIX index were taken from Bloomberg, and Industrial Production was taken from domestic sources.
} 
financial conditions (US high yield spread or VIX), to lagged financial integration and to relevant interactions.

We are aware that endogeneity is a relevant issue in this regression in several dimensions. Specifically, we acknowledge that both industrial production and financial integration can be endogenous to developments in credit markets, and that is the reason for using lags of industrial production and financial integration as independent variables to estimate OLS regressions ${ }^{20}$. We also deal with the endogeneity problem by carrying out IV estimations using Chinn and Ito's de jure integration measure as an instrument for the de facto integration proxy.

Table 3 reports the results of estimating equation (1) for both dependent variables using the two alternative measures of international financial market volatility and alternative estimation techniques (OLS and IV). Columns 1 and 3 report OLS results when the real growth rate of credit is used as the dependent variable, and columns 5 and 7 report the results when using the real interest rate. Columns 2, 4, 6 and 8, report similar results using panel IV methods. In all specifications we allow for the relationship between external and domestic variables to depend on the degree of financial integration.

The results reported in columns $1-4$ suggest that there is a strong correlation between real credit growth and the variables measuring international financial conditions, and that the correlation is stronger the higher the degree of financial integration. In all regressions the coefficients of the log of the high-yield spread and the log of the VIX index interacted with the financial integration proxy have a negative sign and are statistically significant. This evidence suggests that financial integration amplifies the impact of changes in external financial risk on domestic financial markets.

A noteworthy economic implication can be derived from the estimated coefficients. A one standard deviation increase in the log of the high-yield spread (0.41) in our sample is associated with a one percent decline in real credit for a country with average financial integration $^{21}$. This is a sizeable value given that the average real growth rate of credit in the sample is close to one percent. Similarly a one standard deviation increase in the log of the VIX index $(0.33)$ is associated with a 0.8 percent decline in real credit $^{22}$.

\footnotetext{
${ }^{20}$ An alternative measurement of de facto financial integration is BIS data that includes external claims of international banks on Latin America as well as local claims of foreign banks on the region. This variable, however, suffers from more serious endogeneity problems than the LM-F measure. The reason is that local claims of foreign banks are, to a large extent, a component of total domestic credit.

${ }^{21}$ Average financial integration refers to the mean of the measure of financial integration for countries in the sample throughout the sample period.

${ }^{22}$ To provide additional context for this estimations, for a country with average financial integration the rise in the High Yield Spreads and in the VIX Index observed during the recent financial crisis, would predict a 2.3\% and 1.8\% fall in real credit. This rise in our sample corresponds to the change in the High Yield Spreads and the VIX index between the second and fourth quarters of 2008. Such rises account for approximately $1000 \mathrm{bps}$ in the High Yield Spread and for 16 points in the VIX Index.
} 
Table 3: Cross Country Results

\begin{tabular}{|c|c|c|c|c|c|c|c|c|}
\hline \multirow{3}{*}{$\frac{\text { Dependent Variable: }}{\Delta \log \left(\mathrm{IP}_{\mathrm{it}-1}\right)}$} & 1 & 2 & 3 & 4 & 5 & 6 & 7 & 8 \\
\hline & \multicolumn{4}{|c|}{$\Delta \log (\text { Real Credit })_{\text {it }}$} & \multicolumn{4}{|c|}{ Real Interest Rate ${ }_{i t}$} \\
\hline & $0.0567^{* \star *}$ & $0.0364^{*}$ & $0.0611^{* \star *}$ & 0.0319 & -0.0365 & -0.0332 & $-0.0462^{*}$ & -0.0417 \\
\hline & {$[0.017]$} & {$[0.020]$} & {$[0.017]$} & {$[0.019]$} & {$[0.028]$} & {$[0.030]$} & {$[0.025]$} & {$[0.028]$} \\
\hline \multirow[t]{2}{*}{$\Delta \log \left(\mathrm{IP}_{\mathrm{it}-1}\right)^{*} \operatorname{Integration}_{\mathrm{it}-1}$} & 0.0157 & -0.0307 & $0.0245^{\star *}$ & -0.0291 & -0.0230 & -0.00515 & $-0.0302^{*}$ & -0.0227 \\
\hline & {$[0.012]$} & {$[0.020]$} & {$[0.012]$} & {$[0.020]$} & {$[0.018]$} & {$[0.028]$} & {$[0.017]$} & {$[0.026]$} \\
\hline \multirow[t]{2}{*}{$\log \left(\right.$ High Yield Spread $\left._{t}\right)$} & -0.00131 & 0.0114 & & & $-0.0252^{* *}$ & $-0.0265^{\star}$ & & \\
\hline & {$[0.007]$} & {$[0.009]$} & & & {$[0.012]$} & {$[0.014]$} & & \\
\hline \multirow[t]{2}{*}{$\log \left(\text { High Yield Spread }_{t}\right)^{*}$ Integration $_{\text {it- } 1}$} & $-0.0203^{* * *}$ & $-0.0314^{\star * *}$ & & & $0.0411^{* * *}$ & $0.0431^{* * *}$ & & \\
\hline & {$[0.005]$} & {$[0.006]$} & & & {$[0.008]$} & {$[0.010]$} & & \\
\hline \multirow[t]{2}{*}{$\log \left(\mathrm{VIX}_{\mathrm{t}}\right)$} & & & 0.00215 & 0.0118 & & & -0.00918 & $-0.0489^{\star \star \star}$ \\
\hline & & & {$[0.008]$} & {$[0.010]$} & & & {$[0.011]$} & {$[0.015]$} \\
\hline \multirow[t]{2}{*}{$\log \left(\mathrm{VIX} \mathrm{X}_{\mathrm{t}}\right)^{*}$ Integration $_{\mathrm{it}-1}$} & & & $-0.0218^{* * *}$ & $-0.0314^{\star * *}$ & & & $0.0424^{* * *}$ & $0.0781^{\star * *}$ \\
\hline & & & {$[0.005]$} & {$[0.008]$} & & & {$[0.008]$} & {$[0.012]$} \\
\hline \multirow[t]{2}{*}{ Integration $_{\text {it-1 }}$} & $0.147^{\star \star \star}$ & $0.217^{\star * \star}$ & $0.0831^{* * *}$ & $0.108^{* * *}$ & $-0.255^{\star * *}$ & $-0.258^{* * *}$ & $-0.133^{* * *}$ & $-0.235^{\star * *}$ \\
\hline & {$[0.034]$} & {$[0.042]$} & {$[0.018]$} & {$[0.026]$} & {$[0.055]$} & {$[0.068]$} & {$[0.026]$} & {$[0.038]$} \\
\hline Observations & 724 & 711 & 812 & 799 & 809 & 793 & 893 & 880 \\
\hline Overall R-squared & 0.129 & 0.126 & 0.110 & 0.103 & 0.0553 & 0.0711 & 0.0562 & 0.0598 \\
\hline Between R-squared & 0.0116 & 0.00449 & 0.00820 & 0.00243 & 0.0254 & 0.124 & 0.0457 & 0.00138 \\
\hline Within R-squared & 0.166 & 0.149 & 0.136 & 0.112 & 0.0697 & 0.0705 & 0.0849 & 0.0635 \\
\hline Number of Countries & 18 & 18 & 18 & 18 & 18 & 18 & 18 & 18 \\
\hline Country Fixed Effects & Yes & Yes & Yes & Yes & Yes & Yes & Yes & Yes \\
\hline Seasonal dummies & Yes & Yes & Yes & Yes & Yes & Yes & Yes & Yes \\
\hline Estimation method & OLS & IV & OLS & IV & OLS & IV & OLS & IV \\
\hline Sample & \multicolumn{2}{|c|}{ 1997.I-2008.IV } & \multicolumn{2}{|c|}{ 1996.I-2008.IV } & 1997.I & -2008.IV & \multicolumn{2}{|c|}{ 1996.I-2008.IV } \\
\hline
\end{tabular}

Panels (a) and (b) of Figure 5, plot the marginal impact of increasing the high-yield spread and the VIX index, respectively, on the real growth rate of credit. Note that according to the regressions, this impact depends on the level of integration. Specifically the marginal impact an increase in these measures is given by:

$$
\frac{\partial X_{i t}}{\partial Y_{t}}=\beta_{1}+\beta_{2} \text { Int }_{i t-1}
$$

where, as above, $\mathrm{X}$ represents either real credit growth or the real interest rate, and $\mathrm{Y}$ is either the log of the high-yield spread or the log of the value of the VIX index. Panels (a) and (b) of Figure 5 depict equation (2) for the range that the integration measure takes in our sample, with appropriate confidence intervals ${ }^{23}$. The figure clearly shows that there is a range where financial integration is so low that real credit growth is not affected by external financial shocks. As financial integration rises, the impact of external shocks becomes negative and highly significant $^{24}$.

\footnotetext{
23 Note that the relevant standard error for the estimated marginal impact is given by: $\sigma=\sqrt{\operatorname{var}\left(\beta_{1}\right)+\operatorname{var}\left(\beta_{2}\right) * \text { int }_{i, t-1}^{2}+2 \operatorname{cov}\left(\beta_{1} \beta_{2} \text { int }_{i, t-1}\right)}$

${ }^{24}$ Graphs in this figure are constructed using IV estimates.
} 


\section{Figure 5: Marginal Effects of Foreign Financial Shocks on Real Credit Growth and Real Interest Rates}

(a) Impact of High Yield Spread on Real Credit Growth

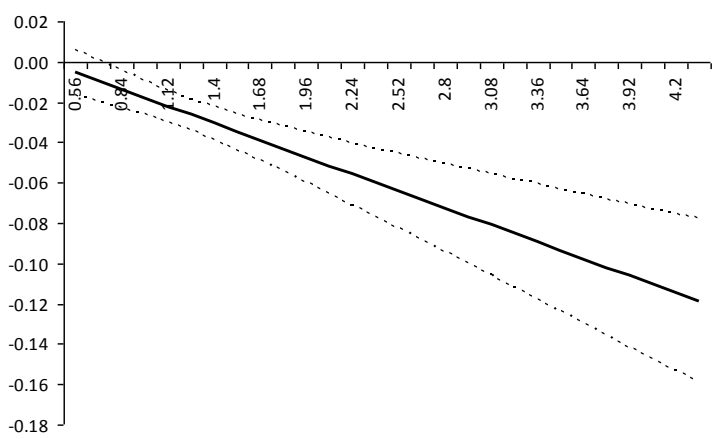

Integration

(c) Impact of High Yield Spread on Real Interest Rates

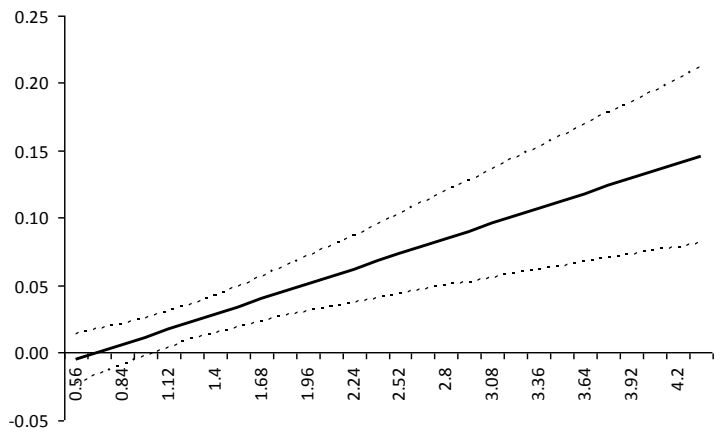

(b) Impact of VIX Index on Real Credit Growth

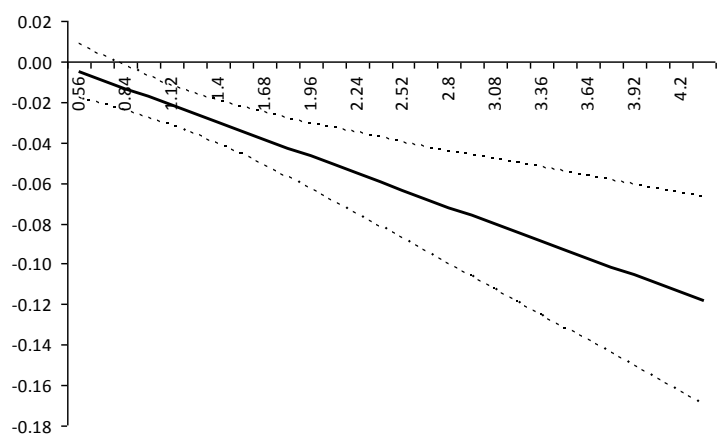

Integration

(d) Impact of VIX Index on Real Interest Rates

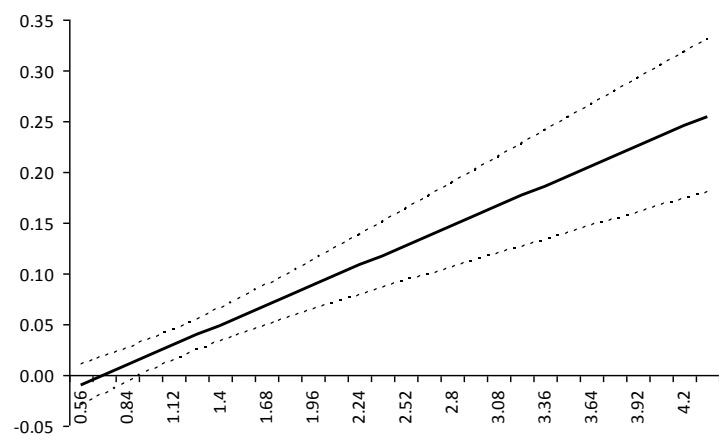

Integration

Turning to the behavior of the real interest rate, in columns $5-8$ of Table 3 , the coefficients of the interactions between the high yield spread and the VIX index with the integration measure are positive in significant, indicating that the correlation between external and domestic financial variables increases with the degree of integration.

Once again, the estimated coefficients can be utilized to derive additional important implications. A one-standard-deviation increase in the log of the high-yield spread or in the $\log$ of the VIX is associated with a 1 and 1.2 percentage points increase in the real interest rate, respectively, for a country with average financial integration ${ }^{25}$. Again, these are meaningful figures, considering that the average real interest rate for the sample period was 1.8 percent.

Panels (c) and (d) in figure 5 depict the estimated marginal impact of an increase in the high-yield spread and the VIX index, respectively, on the real interest rate. We find a positive

\footnotetext{
${ }^{25}$ As above, the fluctuations in the High Yield Spreads and the VIX index observed during the recent financial crisis (between the second and fourth quarters of 2008 in our sample) suggest that real interest rates should increase by 200 and 190 basis points respectively.
} 
and significant impact for most levels of integration, and as with credit, we also find that at very low levels of integration the impact is not statistically significant.

A central conclusion that is worth noting from Table 3 is that, for a wide range of international financial shocks, there is a positive association between financial integration and real credit growth even when factoring in the negative effect on credit growth brought about by foreign financial shocks. In other words, the sum of the coefficient estimated for integration and the coefficient estimated for the interaction between the foreign shock and integration is positive for most levels of the foreign shock. Figure 6 depicts estimates similar to those in Figure 5, but focusing on the marginal impact of financial integration on real credit growth and the real interest rate. Namely it plots:

$$
\frac{\partial X_{i t}}{\partial \operatorname{Int} t_{i, t-1}}=\gamma+\beta_{2} Y_{t}+\alpha_{2} \Delta \log \left(I P_{i t-1}\right)
$$

Panels (a) and (b) in Figure 6 report results for real credit growth and (c) and (d) for the real interest rate ${ }^{26}$. They show that for most levels of the High-yield spread and of the VIX index, integration has a positive and significant effect on real credit growth. The effect diminishes as external risks increase and becomes non significant for high levels of risk. In other words in tranquil times the positive effects of financial integration dominate, while in times of crisis the negative effects of financial integration net out the benefits. It is worthwhile noting that in times of crises the overall impact of financial integration is not statistically significant. When measuring risk with the high yield spread, the positive and significant impact of financial integration on credit growth prevails, except for a few tail observations. When measuring it with the VIX index, the positive and significant effect prevails up to a value of 3.09 of the log of the VIX index that in our sample corresponds to approximately the $65^{\text {th }}$ percentile.

Similarly, columns 5-8 suggest that greater integration to international financial markets is associated with, on average, lower interest rates for most levels of financial risk. Panels (c) and (d) of Figure 6 support these findings. However, the results are not as clear cut as with the evidence on credit growth. When risk is measured using the high yield spread we find that through most of the range of high yield spreads, the impact of financial integration is not statistically significant. When measuring risk with the VIX index, we find that for most of the distribution of the VIX index, and up to the $65^{\text {th }}$ percentile of the distribution within our sample, the impact of integration on interest rates is negative and significant.

\footnotetext{
${ }^{26}$ In order to plot equation (3) in the two dimensional graph, we evaluate it in the median value of $\Delta \log (\mathrm{IP})$, that in our sample is equal to zero.
} 


\section{Figure 6: Marginal Effects of Financial Integration on Real Credit Growth and Real Interest Rates}

(a) Impact of Integration on Real Credit Growth

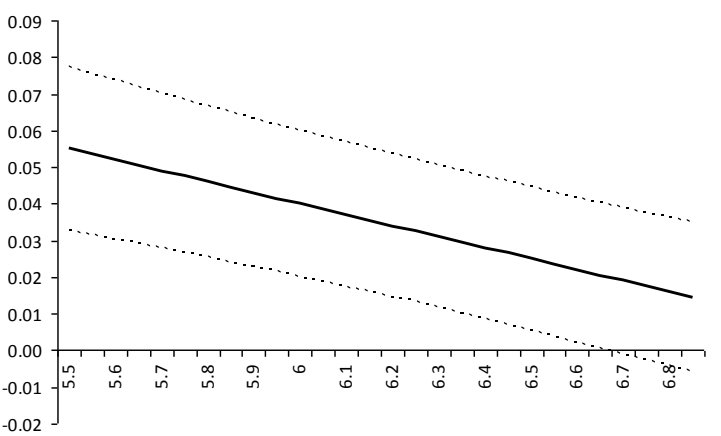

Log(High Yield Spread)

(c) Impact of Integration on Real Interest Rates

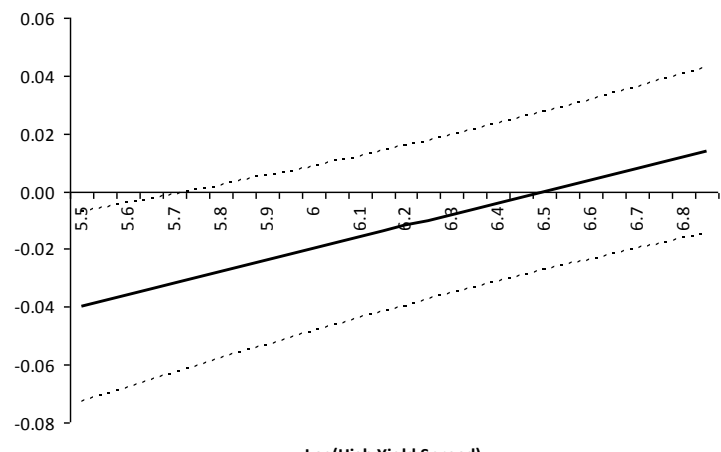

(b) Impact of Integration on Real Credit Growth

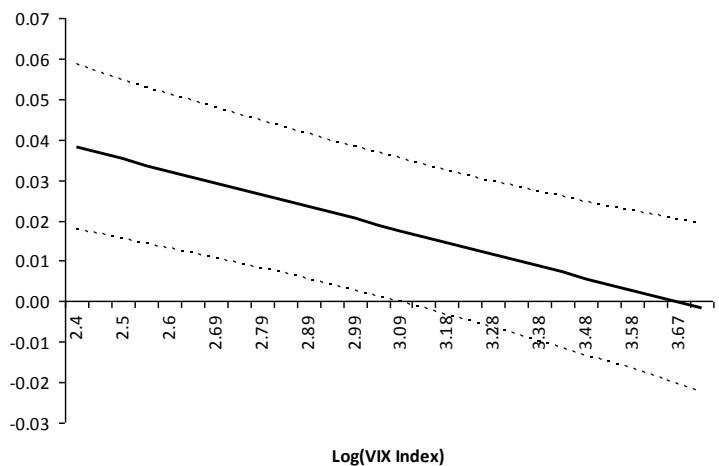

(d) Impact of Integration on Real Interest Rates

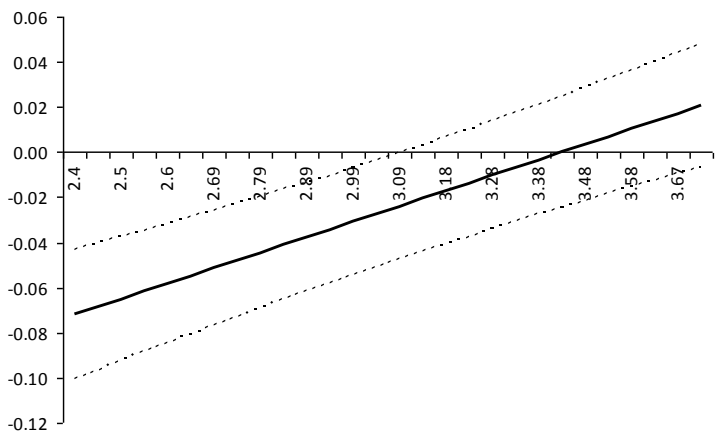

$\log (\mathrm{VIX}$ Index)

Thus, while it is true that deeper financial integration may be a channel through which negative external financial shocks amplify domestic credit contractions and rises in interest rates, it is also true that thanks to financial integration domestic credit markets may deepen and finance may become cheaper. Moreover, as Figure 6 demonstrates, under the vast majority of states of nature, financial integration has a positive effect on deepening credit markets. It is only in cases of very high financial risk that greater financial integration can be related to a decline in real credit growth.

\section{Bank-level Methodology and Results}

This sub-section complements the results above by using bank level data to explore additional conduits through which financial integration may help to propagate international financial shocks into Latin American and Caribbean economies. As noted above, an important mechanism of increased financial integration in Latin America has been enabled through the new presence of foreign banks in the region. 
To assess whether foreign banks have played a role in exacerbating international financial market fluctuations we use a yearly bank-level dataset that covers 476 banks in 17 Latin American and Caribbean countries between 1996 and $2007^{27}$. For that purpose we estimate regressions of the following type:

$$
\begin{aligned}
& X_{b i t}=\alpha X_{b i t-1}+\gamma C_{b i t-1}+\delta_{1} \Delta \log \left(I P_{i t-1}\right)+\delta_{2} \Delta \log \left(I P_{i t-1}\right) * \text { Foreign }_{b i} \\
& +\beta_{1} Y_{t}+\beta_{2} Y_{t} * \text { Foreign }_{b i}+\mu_{b}+\varepsilon_{\text {bit }}
\end{aligned}
$$

Where $b$ denotes a specific bank, $i$ denotes a country and $t$ a time period, $X$ is either the real growth rate of credit supplied by bank $b$ in country $i$ at time $t$ (we measure the change in the logarithm of the stock of real credit of each bank, computed as the bank's nominal credit stock divided by the country's CPI), or the real interest rate (which is obtained by subtracting the observed inflation rate in period $t+l$ from an implicit interest rate--estimated from individual banks' income statements and balance sheets), $C$ is a set of bank-specific controls that include measures of liquidity and capitalization ${ }^{28}, I P$ is the country's industrial production, Foreign is a dummy indicating if the bank is foreign-owned, $\mu_{b}$ are bank fixed effects, $\varepsilon$ is a residual, and $Y$ is the variable measuring international financial conditions. As above, we measure international financial conditions using the log of the high-yield spread and the log of the VIX index. In addition, we now use also the log of the global EMBI spread ${ }^{29}$. We did not use the global EMBI spread in the cross country regressions because it was likely to be an endogenous variable given the inclusion of large emerging market countries in the sample. Since we are now using bank level data, endogeneity of the global EMBI spread is not a relevant issue.

Given that real credit growth and real interest rates are highly persistent at the bank $\operatorname{level}^{30}$, we allow for a lagged dependent variable in our specification. The inclusion of a lagged dependent variable in the context of a panel with fixed effects is well known to generate biased and inconsistent estimates. This is the case because, by construction, the lagged dependent variable will be correlated with the error term. In order to deal with these issues, and following Arellano and Bover (1995) and Blundell and Bond (1998), we use the system GMM estimator ${ }^{31}$.

\footnotetext{
${ }^{27}$ The source of bank level data is BankScope. We use all information available for privately owned banks in Argentina, Bolivia, Brazil, Chile, Colombia, Costa Rica, Ecuador, El Salvador, Guatemala, Honduras, Mexico, Nicaragua, Peru, Paraguay, Trinidad and Tobago, Uruguay, and Venezuela.

${ }^{28}$ Our specification and selection of bank-specific controls follows closely that in Arena, Reinhart and Vázquez (2006). Liquidity is computed as the share of liquid assets in total assets. Liquid assets include cash and reserves, government bonds, and other marketable securities. Capitalization is defined as the ratio of equity capital to total assets.

${ }^{29}$ We use the log of most variables in order to reduce their high variance and ease the interpretation of results so that changes can be interpreted as proxies of growth rates.

${ }^{30}$ Real credit growth is particularly persistent since real credit usually has a trend.

${ }^{31}$ This method relies on differencing the equation to address the problem of possible omitted-variable bias induced by the presence of the bank fixed effects. In addition, and to address the problem of joint endogeneity, lagged values of the independent variables, and lagged values of the dependent variable, are used as instruments for contemporaneous values of independent variables. The results that we report use the system estimator that improves
} 
Table 4 reports results of the bank-level regressions using the real growth rate of credit as the dependent variable ${ }^{32}$. Columns 1,3 , and 5, report regression results without allowing for differential effects from foreign banks. These results suggest that there is a significant negative association between the external financial variables and real credit growth. These relationships are important and sizable from an economic perspective. A one standard deviation increase in the $\log$ of the high-yield spread, in the log of the VIX index, and in the log of the EMBI spread, lead to a 2 percent, 1.9 percent and 2.1 percent contraction in real credit, respectively ${ }^{33}$. These numbers are considerable when compared to the real growth rate of credit during the sample period which was 9.3 percent.

When we allow for a differential effect of foreign banks in columns 2, 4 and 6, we find that domestic banks play a role in propagating the impact of the external financial shock, but that the impact of the shock is amplified by foreign banks. In all three regressions the coefficient of the external financial variable is negative and significant, which should be interpreted as evidence that real credit growth by domestic banks adjusts to foreign financial shocks. Moreover, the coefficient of the interaction between each of the external financial variables and the foreign bank dummy is also significant and negative. These results provide statistical evidence that the adjustment made by foreign banks to their real credit flow is stronger than that of domestic banks. The additional adjustment of foreign banks, according to our estimates, is economically important. Depending on the specification considered, we find that foreign banks adjust their real credit growth between 20 to 30 percent more than the adjustment made by domestic banks.

It is worth noting that the estimated impacts are symmetrical, i.e. when the global economy goes through favorable financial conditions (high-yield spreads are low, and so are the VIX and the EMBI spread) the expansion of real credit by foreign banks is larger than that of domestic ones. When negative financial shocks hit the global economy, the contraction shown by foreign banks is stronger.

As for the rest of the controls, we find that real credit growth is persistent and that lending activity is positively and significantly linked to bank liquidity. We find a positive association between real credit growth and capitalization but this relationship is not estimated precisely. We also find that real credit growth at the bank level is highly pro-cyclical with respect to industrial production. The coefficient associated with IP growth is consistently significant across alternative specifications. However, we do not find evidence of differential behavior between foreign banks and domestic banks regarding pro-cyclicality.

on the standard first differenced GMM estimator by exploiting instruments available for the equations in levels. This improves the precision and reduces the finite sample bias when these additional moment conditions are valid.

${ }^{32} \mathrm{We}$ restrict the instrument matrix in order to avoid biases resulting from over-fitting and weak instruments. We allow up to 4 lags on the relevant variables as instruments.

${ }^{33}$ In order to provide further context for these estimates we also simulate the impact of the recent international financial crisis on real credit growth. During the last year of our sample (2008), the high yield spread increased 1220 basis points, the VIX index 17.5 points and the EMBI spread 475 basis points. According to our estimates this should lead to a contraction of real credit of $4.5 \%, 3.1 \%$ and $4.1 \%$ respectively. 
In table 5 we report similar results using an implicit real interest rate on deposits as the dependent variable. The implicit interest rate is computed as the ratio of interest payments during a given year with respect to the stock of deposits at the beginning of the year. As explained above, the real rate of interest is obtained by subtracting the observed rate of inflation in the following year from the nominal interest rate. Results are similar to and consistent with those reported in table 4. An increase in any of the three measures of international financial conditions is accompanied by an increase in domestic real interest rates. Also, increases in foreign banks' interest rates are larger than those of domestic banks.

For the average bank (without distinguishing between domestic and foreign banks) a one standard deviation rise in the log of the high yield spread is accompanied by a rise of 122 basis points in the real interest rate. The corresponding increases in the real interest rate when the $\log$ of the VIX index or the log of the EMBI spread rises by one standard deviation are 99 and 77 basis points respectively.

Results reported in columns 2, 4 and 6 indicate that foreign banks react more than domestic ones to external financial shocks. In the case of the high yield spread and the EMBI the estimated coefficients reveal that the increase in real interest rates by foreign banks is between 10 to 20 percent larger than that of domestic banks. Independent of the magnitude, the qualitative importance of these results ought to be highlighted: Foreign banks tend to amplify external financial shocks. 
Table 4: Bank Level Results: Real Credit Growth

\begin{tabular}{|c|c|c|c|c|c|c|}
\hline Dependent Variable: $\Delta \log ($ Real Credit) & 1 & 2 & 3 & 4 & 5 & 6 \\
\hline$\Delta \log ($ Real Credit) $[\mathrm{t}-1]$ & $\begin{array}{c}0.175^{\star \star \star} \\
{[0.039]}\end{array}$ & $\begin{array}{c}0.168^{\star * *} \\
{[0.040]}\end{array}$ & $\begin{array}{c}0.163^{* * *} \\
{[0.039]}\end{array}$ & $\begin{array}{c}0.156^{* * *} \\
{[0.039]}\end{array}$ & $\begin{array}{c}0.166^{\star \star *} \\
{[0.040]}\end{array}$ & $\begin{array}{c}0.159^{\star * *} \\
{[0.040]}\end{array}$ \\
\hline log(Liquid Assets/ Total Assets) [t-1] & $\begin{array}{c}0.0730^{* * *} \\
{[0.019]}\end{array}$ & $\begin{array}{c}0.0734^{* * *} \\
{[0.020]}\end{array}$ & $\begin{array}{c}0.0618^{* * *} \\
{[0.019]}\end{array}$ & $\begin{array}{c}0.0623^{* * *} \\
{[0.019]}\end{array}$ & $\begin{array}{c}0.0739^{* * *} \\
{[0.019]}\end{array}$ & $\begin{array}{c}0.0754^{* * *} \\
{[0.019]}\end{array}$ \\
\hline log(Capital/ Assets) [t-1] & $\begin{array}{l}0.0405 \\
{[0.028]}\end{array}$ & $\begin{array}{l}0.0447 \\
{[0.028]}\end{array}$ & $\begin{array}{c}0.013 \\
{[0.032]}\end{array}$ & $\begin{array}{l}0.0145 \\
{[0.033]}\end{array}$ & $\begin{array}{l}0.0346 \\
{[0.035]}\end{array}$ & $\begin{array}{l}0.0355 \\
{[0.035]}\end{array}$ \\
\hline$\Delta \log (\mathrm{IP})[\mathrm{t}-1]$ & $\begin{array}{c}0.255^{\star * *} \\
{[0.037]}\end{array}$ & $\begin{array}{c}0.252^{* * *} \\
{[0.033]}\end{array}$ & $\begin{array}{c}0.246^{* * *} \\
{[0.036]}\end{array}$ & $\begin{array}{c}0.245^{\star * *} \\
{[0.032]}\end{array}$ & $\begin{array}{c}0.250^{* * *} \\
{[0.037]}\end{array}$ & $\begin{array}{c}0.250^{\star * *} \\
{[0.032]}\end{array}$ \\
\hline$\Delta \log (\mathrm{IP})[\mathrm{t}-1]^{*}$ Foreign & & $\begin{array}{l}0.0143 \\
{[0.106]}\end{array}$ & & $\begin{array}{c}-0.000611 \\
{[0.107]}\end{array}$ & & $\begin{array}{c}0.00259 \\
{[0.105]}\end{array}$ \\
\hline $\begin{array}{l}\log (\text { High Yield Spreads }) \\
\log (\text { High Yield Spreads }){ }^{*} \text { Foreign }\end{array}$ & $\begin{array}{c}-0.0406^{* * *} \\
{[0.009]}\end{array}$ & $\begin{array}{c}-0.0393^{\star * *} \\
{[0.009]} \\
-0.00759^{* *} \\
{[0.003]}\end{array}$ & & & & \\
\hline $\begin{array}{l}\log (\mathrm{VIX}) \\
\log (\mathrm{VIX}){ }^{*} \text { Foreign }\end{array}$ & & & $\begin{array}{c}-0.0512^{* * *} \\
{[0.015]}\end{array}$ & $\begin{array}{c}-0.0472^{\star \star *} \\
{[0.015]} \\
-0.0143^{\star *} \\
{[0.006]}\end{array}$ & & \\
\hline $\begin{array}{l}\log (E M B I) \\
\log (E M B I) * \text { Foreign }\end{array}$ & & & & & $\begin{array}{c}-0.0389^{* * *} \\
{[0.010]}\end{array}$ & $\begin{array}{c}-0.0371^{\star * *} \\
{[0.010]} \\
-0.00702^{* *} \\
{[0.003]} \\
\end{array}$ \\
\hline Observations & 2773 & 2773 & 2773 & 2773 & 2773 & 2773 \\
\hline Number of banks & 520 & 520 & 520 & 520 & 520 & 520 \\
\hline Number of countries & 17 & 17 & 17 & 17 & 17 & 17 \\
\hline Bank fixed effects & Yes & Yes & Yes & Yes & Yes & Yes \\
\hline P-Value AR1 & 0.000 & 0.000 & 0.000 & 0.000 & 0.000 & 0.000 \\
\hline P-Value AR2 & 0.740 & 0.712 & 0.988 & 0.987 & 0.840 & 0.866 \\
\hline P-Value Hansen Stat & 0.404 & 0.417 & 0.388 & 0.405 & 0.336 & 0.327 \\
\hline P-Value F-test 1 & & 0.008 & & 0.016 & & 0.012 \\
\hline P-Value F-test 2 & & 0.000 & & 0.000 & & 0.000 \\
\hline Sample & \multicolumn{6}{|c|}{ Yearly: 1996-2008 } \\
\hline
\end{tabular}

Regarding the rest of the controls, the regressions' results show that, similarly to the behavior of real credit growth, real interest rates are highly persistent. With respect to changes in IP growth, the results indicate an inverse relationship with real interest rates, and there is evidence of differential behavior between domestic and foreign banks. In particular, we find that foreign banks reduce real interest rates more than domestic banks in good times and increase real interest rates more in bad times. With respect to bank-specific controls we find some evidence indicating a negative correlation between interest rates and liquidity, even though it is notable that the coefficients are estimated imprecisely, 
Table 5: Bank Level Results: Real Interest Rate

\begin{tabular}{|c|c|c|c|c|c|c|}
\hline Dependent Variable: Real Interest Rate & 1 & 2 & 3 & 4 & 5 & 6 \\
\hline Real interest rate [t-1] & $\begin{array}{c}0.431^{\star \star \star} \\
{[0.054]}\end{array}$ & $\begin{array}{c}0.429^{\star \star \star} \\
{[0.056]}\end{array}$ & $\begin{array}{c}0.434^{\star \star \star} \\
{[0.050]}\end{array}$ & $\begin{array}{c}0.432^{\star \star \star} \\
{[0.052]}\end{array}$ & $\begin{array}{c}0.435^{\star \star \star} \\
{[0.051]}\end{array}$ & $\begin{array}{c}0.433^{\star \star \star} \\
{[0.052]}\end{array}$ \\
\hline $\log$ (Liquid Assets/ Total Assets) [t-1] & $\begin{array}{c}-0.33 \\
{[0.604]}\end{array}$ & $\begin{array}{c}-0.56 \\
{[0.623]}\end{array}$ & $\begin{array}{c}-2.814^{* * *} \\
{[0.946]}\end{array}$ & $\begin{array}{c}-2.948^{\star * *} \\
{[0.971]}\end{array}$ & $\begin{array}{c}-2.928^{\star * *} \\
{[0.844]}\end{array}$ & $\begin{array}{c}-3.073^{\star * *} \\
{[0.870]}\end{array}$ \\
\hline $\log$ (Capital/ Assets) [t-1] & $\begin{array}{c}1.579 \\
{[2.042]}\end{array}$ & $\begin{array}{c}1.471 \\
{[1.940]}\end{array}$ & $\begin{array}{c}0.424 \\
{[1.431]}\end{array}$ & $\begin{array}{c}0.594 \\
{[1.425]}\end{array}$ & $\begin{array}{c}0.645 \\
{[1.920]}\end{array}$ & $\begin{array}{c}0.77 \\
{[1.911]}\end{array}$ \\
\hline$\Delta \log (\mathrm{IP})[\mathrm{t}-1]$ & $\begin{array}{l}-5.083^{* *} \\
{[2.220]}\end{array}$ & $\begin{array}{l}-0.956 \\
{[1.314]}\end{array}$ & $\begin{array}{l}-4.263^{*} \\
{[2.410]}\end{array}$ & $\begin{array}{l}0.0407 \\
{[1.337]}\end{array}$ & $\begin{array}{l}-4.754^{*} \\
{[2.436]}\end{array}$ & $\begin{array}{l}-0.389 \\
{[1.372]}\end{array}$ \\
\hline$\Delta \log (\mathrm{IP})[\mathrm{t}-1]{ }^{*}$ Foreign & & $\begin{array}{l}-16.02 \\
{[9.728]}\end{array}$ & & $\begin{array}{l}-16.40^{*} \\
{[9.674]}\end{array}$ & & $\begin{array}{l}-16.65^{\star} \\
{[9.894]}\end{array}$ \\
\hline log(High Yield Spreads) & $\begin{array}{c}2.873^{* * *} \\
{[0.564]}\end{array}$ & $\begin{array}{c}2.649^{* * *} \\
{[0.570]}\end{array}$ & & & & \\
\hline $\log ($ High Yield Spreads) * Foreign & & $\begin{array}{l}0.280^{\star *} \\
{[0.134]}\end{array}$ & & & & \\
\hline $\log (\mathrm{VIX})$ & & & $\begin{array}{c}2.969^{* * *} \\
{[0.655]}\end{array}$ & $\begin{array}{c}2.747^{* * *} \\
{[0.624]}\end{array}$ & & \\
\hline $\log (\mathrm{VIX}){ }^{*}$ Foreign & & & & $\begin{array}{l}0.631^{* *} \\
{[0.296]}\end{array}$ & & \\
\hline $\log (E M B I)$ & & & & & $\begin{array}{c}1.383^{\star * *} \\
{[0.470]}\end{array}$ & $\begin{array}{c}1.308^{* * *} \\
{[0.451]}\end{array}$ \\
\hline $\log (E M B I) *$ Foreign & & & & & & $\begin{array}{l}0.281^{*} \\
{[0.147]}\end{array}$ \\
\hline Observations & 2026 & 2026 & 2026 & 2026 & 2026 & 2026 \\
\hline Number of banks & 439 & 439 & 439 & 439 & 439 & 439 \\
\hline Number of countries & 17 & 17 & 17 & 17 & 17 & 17 \\
\hline Bank fixed effects & Yes & Yes & Yes & Yes & Yes & Yes \\
\hline P-Value AR1 & 0.005 & 0.005 & 0.002 & 0.002 & 0.002 & 0.002 \\
\hline P-Value AR2 & 0.522 & 0.454 & 0.959 & 0.905 & 0.934 & 0.989 \\
\hline P-Value Hansen Stat & 0.519 & 0.471 & 0.685 & 0.686 & 0.652 & 0.633 \\
\hline P-Value F-test 1 & & 0.077 & & 0.091 & & 0.084 \\
\hline P-Value F-test 2 & & 0.000 & & 0.000 & & 0.001 \\
\hline Sample & \multicolumn{6}{|c|}{ Yearly: 1996-2008 } \\
\hline
\end{tabular}

${ }^{* * *} p<0.01,{ }^{* *} p<0.05,{ }^{*} p<0.1$. Clustered standard errors in brackets. F-test 1 is a test under the null hypothesis that the sum of the coefficient of IP growth and the coefficient of IP growth interacted with the foreign bank dummy is zero. F-test 2 is a test under the null hypothesis that the sum of the coefficient of the external variable (high yield spread, VIX, or EMBI) and the coefficient of it interacted with the foreign bank dummy is zero. Regressions are estimated using the bank's relative size in each country and time period as a weight.

An important question that comes out from the analysis above is whether all foreign banks behave equally. There is ample discussion on how different types of foreign banks follow different models when locating abroad. In particular in Latin America, there is a wide perception that the model followed by Spanish banks is different, and that their home office has given them guidelines to behave as a domestic bank. In order to test whether there are differences in the way foreign banks from different origins behave, we re-estimate equation (4) separating foreign banks into three categories: banks of US origin, banks of Spanish origin, and other foreign banks. The last category includes mostly European banks from countries other than Spain, some Canadian banks, and some additional banks coming from Australia, Israel, Japan, Korea and Taiwan. Table 6 reports results of these estimations, once again using the real growth rate of credit (columns $1-3$ ) and the real interest rate (columns $4-6$ ) as dependent variables.

The estimated coefficients for the relevant interactions reveal that in fact foreign banks from different origin follow different behavior. Most notably, we find no significant differences between the behavior of Spanish banks and domestic banks regarding the behavior of either real 
credit or real interest rates. ${ }^{34}$ With respect to US banks, our results suggest that they strongly amplify the effects of external shocks on real credit growth but we do not find differences in the way they adjust interest rates. Foreign banks of other origins also amplify external financial shocks by contracting credit more than domestic banks and they also increase real interest rates more than domestic banks. Thus, other foreign banks largely account for the result (reported in table 5) that foreign banks increase interest rates more than domestic banks in the presence of an adverse financial shock. Note that these results are consistent across alternative measures of external financial conditions used throughout the analysis.

Table 6: Bank Level Results: By Bank Origin

\begin{tabular}{|c|c|c|c|c|c|c|}
\hline \multirow{3}{*}{$\begin{array}{l}\text { Dependent Variable: } \\
\Delta \log (\text { Real Credit) [t-1] }\end{array}$} & 1 & 2 & 3 & \multirow{2}{*}{\multicolumn{3}{|c|}{$\begin{array}{c}5 \\
\text { Real interest rate }\end{array}$}} \\
\hline & \multicolumn{3}{|c|}{$\Delta \log ($ Real Credit) } & & & \\
\hline & $\begin{array}{l}0.173^{* * *} \\
{[0.034]}\end{array}$ & $\begin{array}{c}0.164^{* * *} \\
{[0.033]}\end{array}$ & $\begin{array}{c}0.166^{* * *} \\
{[0.033]}\end{array}$ & & & \\
\hline Real interest rate $[\mathrm{t}-1]$ & & & & $\begin{array}{c}0.432^{\star * \star} \\
{[0.055]}\end{array}$ & $\begin{array}{c}0.434^{\star \star \star} \\
{[0.052]}\end{array}$ & $\begin{array}{c}0.435^{\star \star \star} \\
{[0.052]}\end{array}$ \\
\hline $\log$ (Liquid Assets/ Total Assets) [t-1] & $\begin{array}{c}0.0707^{* * *} \\
{[0.017]}\end{array}$ & $\begin{array}{c}0.0566^{* * *} \\
{[0.016]}\end{array}$ & $\begin{array}{c}0.0713^{\star \star \star} \\
{[0.016]}\end{array}$ & $\begin{array}{l}-1.034^{*} \\
{[0.609]}\end{array}$ & $\begin{array}{l}-3.168^{\star * *} \\
{[0.980]}\end{array}$ & $\begin{array}{c}-3.378^{\star * *} \\
{[0.878]}\end{array}$ \\
\hline $\log$ (Capital/ Assets) [t-1] & $\begin{array}{l}0.0482^{*} \\
{[0.025]}\end{array}$ & $\begin{array}{l}0.0311 \\
{[0.027]}\end{array}$ & $\begin{array}{l}0.0539^{*} \\
{[0.029]}\end{array}$ & $\begin{array}{c}0.63 \\
{[1.769]}\end{array}$ & $\begin{array}{c}0.467 \\
{[1.335]}\end{array}$ & $\begin{array}{c}0.506 \\
{[1.797]}\end{array}$ \\
\hline$\Delta \log (\mathrm{IP})[\mathrm{t}-1]$ & $\begin{array}{l}0.262^{* * *} \\
{[0.032]}\end{array}$ & $\begin{array}{l}0.255^{* * *} \\
{[0.032]}\end{array}$ & $\begin{array}{l}0.262^{* * *} \\
{[0.032]}\end{array}$ & $\begin{array}{l}-1.486 \\
{[1.445]}\end{array}$ & $\begin{array}{l}-0.367 \\
{[1.423]}\end{array}$ & $\begin{array}{l}-0.802 \\
{[1.462]}\end{array}$ \\
\hline$\Delta \log (\mathrm{IP})[\mathrm{t}-1]{ }^{*}$ Foreign USA & $\begin{array}{l}-0.0212 \\
{[0.231]}\end{array}$ & $\begin{array}{l}-0.0545 \\
{[0.224]}\end{array}$ & $\begin{array}{l}-0.0627 \\
{[0.230]}\end{array}$ & $\begin{array}{c}-2.46 \\
{[7.194]}\end{array}$ & $\begin{array}{l}-2.813 \\
{[6.947]}\end{array}$ & $\begin{array}{l}-3.088 \\
{[6.985]}\end{array}$ \\
\hline$\Delta \log (\mathrm{IP})[\mathrm{t}-1]{ }^{*}$ Foreign Spain & $\begin{array}{c}0.00274 \\
{[0.132]}\end{array}$ & $\begin{array}{c}-0.00257 \\
{[0.136]}\end{array}$ & $\begin{array}{l}-0.0108 \\
{[0.135]}\end{array}$ & $\begin{array}{c}-9.818 \\
{[10.004]}\end{array}$ & $\begin{array}{l}-9.158 \\
{[9.566]}\end{array}$ & $\begin{array}{l}-9.095 \\
{[9.758]}\end{array}$ \\
\hline$\Delta \log (\mathrm{IP})[\mathrm{t}-1]{ }^{*}$ Foreign Other & $\begin{array}{c}0.131 \\
{[0.116]}\end{array}$ & $\begin{array}{c}0.139 \\
{[0.109]}\end{array}$ & $\begin{array}{c}0.149 \\
{[0.108]}\end{array}$ & $\begin{array}{l}-43.63^{* *} \\
{[19.631]}\end{array}$ & $\begin{array}{l}-43.35^{\star *} \\
{[19.047]}\end{array}$ & $\begin{array}{l}-45.42^{* *} \\
{[18.979]}\end{array}$ \\
\hline log(High Yield Spreads) & $\begin{array}{c}-0.0391^{* * *} \\
{[0.008]}\end{array}$ & & & $\begin{array}{c}2.332^{\star \star \star} \\
{[0.540]}\end{array}$ & & \\
\hline $\log ($ High Yield Spreads) * Foreign USA & $\begin{array}{c}-0.0152^{* * *} \\
{[0.005]}\end{array}$ & & & $\begin{array}{c}0.103 \\
{[0.166]}\end{array}$ & & \\
\hline $\log ($ High Yield Spreads) * Foreign Spain & $\begin{array}{c}0.000271 \\
{[0.004]}\end{array}$ & & & $\begin{array}{c}0.202 \\
{[0.177]}\end{array}$ & & \\
\hline $\log \left(\right.$ High Yield Spreads) ${ }^{*}$ Foreign Other & $\begin{array}{c}-0.00832^{* * *} \\
{[0.003]}\end{array}$ & & & $\begin{array}{c}0.487^{* * *} \\
{[0.155]}\end{array}$ & & \\
\hline $\log (\mathrm{VIX})$ & & $\begin{array}{c}-0.0539^{* * *} \\
{[0.013]}\end{array}$ & & & $\begin{array}{c}3.102^{\star \star \star} \\
{[0.668]}\end{array}$ & \\
\hline $\log (\mathrm{VIX}){ }^{*}$ Foreign USA & & $\begin{array}{c}-0.0275^{\star * *} \\
{[0.009]}\end{array}$ & & & $\begin{array}{c}0.352 \\
{[0.405]}\end{array}$ & \\
\hline $\log (\mathrm{VIX}){ }^{*}$ Foreign Spain & & $\begin{array}{c}0.000924 \\
{[0.008]}\end{array}$ & & & $\begin{array}{c}0.218 \\
{[0.392]}\end{array}$ & \\
\hline $\log (\mathrm{VIX}){ }^{*}$ Foreign Other & & $\begin{array}{c}-0.0168^{* * *} \\
{[0.006]}\end{array}$ & & & $\begin{array}{l}1.181^{* * *} \\
{[0.347]}\end{array}$ & \\
\hline $\log (E M B I)$ & & & $\begin{array}{c}-0.0419^{* * *} \\
{[0.009]}\end{array}$ & & & $\begin{array}{c}1.565^{\star * *} \\
{[0.443]}\end{array}$ \\
\hline $\log (\mathrm{EMBI}){ }^{*}$ Foreign USA & & & $\begin{array}{c}-0.0142^{* * *} \\
{[0.005]}\end{array}$ & & & $\begin{array}{c}0.186 \\
{[0.185]}\end{array}$ \\
\hline $\log (E M B I) *$ Foreign Spain & & & $\begin{array}{l}0.00135 \\
{[0.004]}\end{array}$ & & & $\begin{array}{l}0.0555 \\
{[0.203]}\end{array}$ \\
\hline $\log (\mathrm{EMBI}){ }^{*}$ Foreign Other & & & $\begin{array}{c}-0.00824^{* * *} \\
{[0.003]}\end{array}$ & & & $\begin{array}{l}0.569^{* * *} \\
{[0.166]}\end{array}$ \\
\hline Observations & 2773 & 2773 & 2773 & 2018 & 2018 & 2018 \\
\hline Number of banks & 521 & 521 & 521 & 439 & 439 & 439 \\
\hline Number of countries & 17 & 17 & 17 & 17 & 17 & 17 \\
\hline P-Value AR1 & 0.000 & 0.000 & 0.000 & 0.003 & 0.002 & 0.001 \\
\hline P-Value AR2 & 0.613 & 0.924 & 0.925 & 0.956 & 0.594 & 0.513 \\
\hline P-Value Hansen Stat & 0.470 & 0.415 & 0.392 & 0.453 & 0.643 & 0.636 \\
\hline Sample & & & Yearly: & $6-2008$ & & \\
\hline
\end{tabular}

\footnotetext{
${ }^{34}$ Because (in contrast with other foreign banks) Spanish banks fund themselves mostly through domestic deposits, this result using bank-level data may be similar to that of Kamil and Rai (2009) who, using BIS aggregate data, find that total foreign bank lending is less sensitive to changes in TED spreads and expected default probabilities when banks fund themselves through domestic deposits.
} 


\section{Some Policy Recommendations Regarding the Operations of Foreign Banks}

An important result from the analysis in this paper is that foreign banks operating in Latin America tend to amplify external financial shocks. That is, following deterioration (improvement) in external financial conditions, foreign banks tend to decrease (increase) real credit growth and increase (decrease) real interest rates more than domestic banks.

This result needs to be interpreted with caution when deriving policy recommendations. For example, although this paper has focused on the response of foreign banks to external financial shocks, other studies emphasize the positive role played by foreign banks when adverse shocks are generated locally (see section II). Of particular interest is the result found in the literature that foreign banks can stabilize credit during episodes of domestic deposit crunches. Thus, the policy conclusion derived from this paper is not that participation of foreign banks in Latin America should be constrained. Instead, the main policy conclusion is that strategies need to be designed to avoid excessive transmission of foreign financial shocks into domestic economies, while preserving the gains of greater financial depth obtained through financial integration. ${ }^{35}$

Latin American regulators are particularly concerned with the possibility of a struggling foreign parent bank that may force inadequate transfers from its branches operating in Latin America in order to cover its losses. Similarly, there is the concern that the home-country authorities of a parent house in problems may order the liquidation of branches operating abroad. This could create problems in the host country of the foreign branch if the branch is systemically important. The heated debate in 2009 in both Mexico and the US about whether Citibank would need to sell its profitable foreign branch in Mexico (Banamex) is an example of these concerns.

There are three areas of policy actions that Latin American policymakers need to consider to deal with this issue: (a) the establishment of adequate ring fencing arrangements; (b) the development of early warning systems and (c) the implementation of agreements of collaboration between home- and host-country supervisors. Each of these is now discussed in turn.

\section{Ring Fencing}

The so-called ring-fencing mechanisms are commonly used by international banks from developed countries to limit the losses a bank might face due to problems in its foreign branches. For example in the United States, the Federal Reserve Act establishes that the parent house of a

\footnotetext{
${ }^{35}$ Also, the results in this paper regarding the country of origin of foreign banks might also be reflecting different forms of bank models during the period under study. In other words, the results could be indicating that foreign banks that fund themselves mostly through domestic deposits (a typical modus operandi of Spanish banks in the 2000s) tend to reduce credit expansion relatively less in the presence of an adverse financial shock than those whose main funding take place through external liabilities. Since branches of foreign banks have often changed their model of operation in Latin America, policy recommendations would be misleading if they focus on the specific nationality of the parent house of foreign banks.
} 
US bank is not obliged to provide liquidity support for withdrawals of deposits raised by a foreign branch in its host country if the branch faces severe troubles and its problems can be attributed to policies or actions originated in the host country (such as expropriation, exchange rate controls or the eruption of war).

Ring-fencing mechanisms can, and should, also be implemented by host country authorities in Latin America to be able to take apart" the assets of a foreign branch from those of its parent house in either of two cases: (a) the parent house of a foreign bank (or the home country authorities of the foreign bank) decides to declare bankruptcy of the bank on a consolidated basis, even if the branch operating in the host country is solvent; or (b) the branch faces severe financial problems, but it is considered systemically important in the host country and, therefore, host country authorities need to intervene through liquidation procedures that minimize contagion to the rest of the financial system.

Banking regulation in the State of New York provides an example of the usage of ringfencing mechanisms to protect the assets of a foreign branch. The law establishes that, in case of insolvency of the parent house of a foreign branch, creditors with residence in the State of New York have preference over other creditors with respect to the assets of the foreign branch. In Latin America, the banking regulations in Chile and Peru contain similar provisions. In these two countries, domestic banks and branches of foreign banks are treated equally both in terms of regulations, access to the deposit insurance and adherence to supervisory requirements.

While this type of ring-fencing has important elements of discrimination since it favors local creditors versus foreign creditors of a foreign branch, it does not violate the -nondiscrimination" principle contained in free trade agreements (FTAs). The reason is that FTAs in Latin America allow the adoption or maintenance of measures for prudential reasons. The intervention by host country authorities of a troubled foreign branch in order to avoid a systemic crisis is an example of an intervention for prudential reasons.

\section{Early Warning Systems}

A number of supervisory authorities in Latin America have developed early warning systems for the purpose of identifying emerging problems in financial institutions. These systems are usually formed by indicators assessing deviations from adequate capitalization, liquidity and other key variables of bank strength. The proposal advanced here is to expand traditional early warning systems to include specific bank-soundness indicators regarding foreign branches. In particular, it is proposed to include two indicators:

\section{a. Frequency and value of transfers abroad.}

This indicator would need to assess the frequency and value of transfers of funds from the branches of foreign banks to their parent houses. The indicator should produce a warning signal when the transfers reach a frequency and/or a value above a pre-determined threshold. The value 
of the threshold could be determined according to the normal practices of similar institutions and/or the branch's history of transfers abroad. The concept behind this indicator is similar to that used by credit card companies, who question a customer when he/she realizes unusual transactions or if the value of those transactions exceeds the usual activities of the customer.

b. Financial strength of parent houses of foreign branches and quality of home-country supervisors

As the 2008-09 international financial crisis demonstrated, the origin of banks does not constitute guarantee about the solvency of financial institutions. While banks from industrial countries suffered major solvency problems during the recent crisis, banking systems in Latin America remained sound and well-capitalized. This development leads to two important lessons for policymakers in the region. The first is that it is essential for bank supervisors in Latin America to systematically assess market indicators regarding the financial condition of large international banks establishing branches in the region. While this information might be both insufficient and incomplete, the lesson is that local bank supervisors in the region need to be more alert than in the past about global financial developments, including those that might compromise the quality of the supervisory capacity of industrial countries. The second lesson is that supervisors in the region need to have a clear plan of action in case early warning indicators provide a signal about emerging problems in the parent house of a foreign bank or the supervisory quality in the home country of the parent bank. Further analysis and research is certainly needed in this area.

\section{Signing and Implementation of Agreements of Collaboration between Home- and Host-Country Supervisors}

This recommendation is not new in many Latin American countries and some progress has been achieved, although much remains to be done. There are two key issues. The first is the actual signing of a letter of agreement. In the past, a number of countries in the region have not been able to obtain these agreements with a number of industrial countries (Spain is among the few exceptions), especially when the objective of the agreement is to: (a) exchange timely information regarding the financial situation of the foreign banks and their branches operating in the countries that sign the agreement and (b) ensure that the supervisory authorities in both countries collaborate in the process of in-situ supervision for the purpose of achieving consolidated supervision in accordance with accepted international standards.

The second issue, and one even more difficult to resolve, is obtaining the recognition and legal acceptance from industrial-country authorities regarding the local procedures for resolving banking problems (including intervention of the foreign branch) existing in Latin American countries. Strong support from multilateral organizations for the signature of these agreements can help to minimize (if not completely eliminate) the legal interpretation problems that might 
arise in case the law in a Latin American country oblige the local authorities to intervene the branch of a foreign bank.

\section{Concluding Remarks}

Financial integration in Latin America and the Caribbean, as measured by alternative methodologies, is high. Both from a de jure and a de facto point of view, the region appears to be notoriously more integrated to international financial markets than other regions of the developing world. The propagation of the recent crisis from developed economies to emerging economies, including Latin America, through financial channels has raised concerns about the appropriateness of maintaining a highly open capital account. This paper contributes to the literature by providing evidence that under most states of nature, financial integration has a positive effect on deepening local financial markets. It is only in cases of very high international financial risk that greater financial integration can be related to a decline in real credit growth. Indeed, the empirical analysis demonstrates that while financial integration amplifies the impact of international financial shocks on aggregate real credit and real interest rate fluctuations, the net impact of integration on deepening credit markets prevails in most occasions. Evidence on financial integration reducing interest rates in most states of nature is not as conclusive.

One crucial dimension of financial integration that has been developing rapidly in Latin America in the past decade is through greater participation of foreign owned banks. The impact of foreign bank penetration in developing countries has been studied widely, and in general points to favorable conclusions, such as improvements in technology, improved methods for financial and risk management, and greater competition. In this paper we explored the role of foreign banks in propagating foreign financial shocks to the local financial systems of Latin America. Our main finding is that, in general, foreign banks tend to amplify the impact of foreign financial fluctuations on domestic financial variables. However, the results also show that origin matters, and that Spanish banks tend to react less than other foreign banks to changes in risk conditions in the international capital markets.

From a policy perspective, these findings need to be interpreted with caution, as they do not call for banning or reducing foreign bank participation in Latin America. Instead they call for strategies that avoid excessive transmission of foreign financial shocks into domestic economies while preserving the gains of greater financial depth obtained through financial integration. Policies such as ring-fencing, the development of early-warning indicators and the incorporation of agreements with foreign supervisors, ought to be considered to prevent financial weakness in Latin American financial systems when international capital markets are in turmoil. 


\section{References}

Arellano M. and Bover O., (1995) Another Look at the Instrumental Variable Estimation of Error-Components Models", Journal of Econometrics 68(1), 29-51.Arellano and Bover (1995)

Arena Marco, Carmen Reinhart and Francisco Vazquez, 2006, The Lending Channel in Emerging Economies: Are Foreign Banks Different”?, NBER Working Paper 12340, Cambridge, June.

Blundell R. and Bond S., (1998) Initial Conditions and Moment Restrictions in Dynamic Panel Data Models", Journal of Econometrics 87, 115-143.

Calvo, Guillermo, Izquierdo, Alejandro, and Ernesto Talvi (2006), Phoenix Miracles in Emerging Markets: Recovering Without Credit from Systemic Financial Crises”, NBER Working Paper No. 12101.

Calvo, Guillermo, and Rudy Loo-Kung (2009), Should We Rush to Further Regulate Financial Institutions?", mimeo.

Chinn, Menzie and Hiro Ito, 2007, A New Measure of Financial Openness”, mimeo, forthcoming, Journal of Comparative Policy Analysis

Cull, Robert, and Maria Soledad Martinez Peria (2007), Foreign Bank Participation and Crises in Developing Countries", World Bank Policy Research Working Paper No. 4128

De Haas, Ralph and Lelyveld, Iman Van (2006), Foreign Banks and Credit Stability in Central and Eastern Europe: A Panel Data Analysis", Journal of Banking and Finance, Vol. 30, pp. 19271952.

Edwards, S. 1999, —-Iw Effective are Capital Controls?"Journal of Economic Perspectives, 13, pp. $65-84$

Glick, R. and M. Hutchison, 2001, Banking and Currency Crises: How Common are Twins? in Financial Crisis in Emerging Markets, ed. By Reuven R. Glick, R. Moreno and M.M. Spiegel, New York: Cambridge University Press.

Galindo, Arturo, Micco, Alejandro and Guillermo Ordoñez (2002) Financial Liberalization: Does It Pay to Join the Party?" Economia, 3(1): 231-261.

Galindo, Arturo, Micco, Alejandro, and Andrew Powell (2003), Eoyal Lenders or Fickle Financiers : Foreign Banks in Latin America", Inter-American Development Bank Research Department Working Paper 529. 
Galindo, Arturo, Schiantarelli, Fabio and Andrew Weiss (2007), "Does Financial Reform Improve the Allocation of Investment? Micro Evidence From Developing Countries", Journal of Development Economics, 83, pp. 562-587.

Goldberg, Linda (2005), The International Exposure of U.S. Banks”, NBER Working Paper 11365, May.

Kamil, Herman and Kulwant Rai (2009), - - n the Eve Retrenchment? The Effect of the Global Credit Crunch on Foreign Banks' Lending in Emerging Markets” IMF. Mimeo.

Lane, Philip R. and Gian Maria Milesi-Ferretti, 2007, —Th£xternal Wealth of Nations Mark II: Revised and Extended Estimates of Foreign Assets and Liabilities, 1970-2004, Journal of International Economics, Elsevier, vol. 73 (2), pp. 223-250, November

Magud, Nicolas and Carmen Reinhart, 2007, Capital Controls: An Evaluation”, NBER Working Paper 11973, Sebastian Edwards (ed.) Capital Controls and Capital Flows in Emerging Economies: Policies, Practices and Consequences, Chicago: Chicago University Press for the NBER.

Martinez Peria, Maria Soledad, Powell, Andrew, and Ivanna Vladkova-Hollar (2005), Banking on Foreigners: The Behavior of International Bank Claims on Latin America, 1985-2000", IMF Staff Papers. 01/02/2005; 52.

Morgan, Donald, and Philip Strahan (2003), Foreign Bank Entry and Business Volatility: Evidence from U.S. States and Other Countries", NBER Working Paper No. 9710.

Peek, Joe, and Eric Rosengren (2000), Collateral Damage: Effects of the Japanese Bank Crisis on Real Activity in the United States.”, American Economic Review 90, no. 1 (March): 30-45.

Quinn, Dennis, 2003, - Capital Account Liberalization and Financial Globalization, 1890-1999: A Synoptic View", International Journal of Finance and Economics, Vol. 8. No. 3, pp 189-204

Ranciere, Romain, Tornell, Aaron, and Frank Westermann (2006), Đecomposing the Effects of Financial Liberalization: Crises vs. Growth", Journal of Banking \& Finance 30, 3331-3348.

Ranciere, Romain, Tornell, Aaron, and Frank Westermann (2008), Systemic Crises and Growth", the Quarterly Journal of Economics, Vol. 123, No. 1, Pages 359-406.

Stiglitz, Joseph (2009), The UN Takes Charge” Demand Side Economics, July 15 